\title{
Preclinical anticancer studies on the ethyl acetate leaf extracts of Datura stramonium and Datura inoxia
}

\author{
Bakht Nasir ${ }^{1}$, Muhammad Waleed Baig ${ }^{1}$, Muhammad Majid ${ }^{1,2}$, Syeda Masooma Ali" \\ Muhammad Zafar Irshad Khan ${ }^{1}$, Syeda Tayyaba Batool Kazmi ${ }^{1}$ and Ihsan-ul Haq ${ }^{1 *}$ (i)
}

\begin{abstract}
Background: Cancer is a horrific disease relentlessly affecting human population round the globe. Genus Datura encompasses numerous species with reported medicinal uses. However, its potential as a source of natural anticancer agents is yet to be determined. Datura stramonium (DS) and Datura inoxia (DI) are the two species chosen for this study.

Methods: Total phenolic and flavonoid content (TPC and TFC) as well as antioxidant activity were assessed through colorimetric method. Polyphenolic quantification was done by RP-HPLC. Following extract standardization ethyl acetate leaf extracts of both species (DSL-EA and DIL-EA) were chosen for anticancer studies. In vitro cytotoxicity using various models including cancer cell lines was monitored. Following toxicity studies, benzene (0.2 ml) was used to induce leukemia in Sprague-Dawley rats. Extracts were orally administered to preventive (100 and $200 \mathrm{mg} /$ $\mathrm{kg})$ and treatment $(200 \mathrm{mg} / \mathrm{kg}$ only) groups. The antileukemic potential of extracts was assessed through haematological, biochemical, endogenous antioxidants and histological parameters.

Results: Significant TPC and TFC were estimated in DSL-EA and DIL-EA. RP-HPLC quantified $(\mu \mathrm{g} / \mathrm{mg}$ extract) rutin $(0.89 \pm 0.03)$, gallic acid $(0.35 \pm 0.07)$, catechin $(0.24 \pm 0.02)$ and apigenin $(0.29 \pm 0.09)$ in DSL-EA while rutin (0.036 \pm $0.004)$ and caffeic acid $(0.27 \pm 0.03)$ in DIL-EA. Both extracts exhibited significant brine shrimp cytotoxicity $\left(\mathrm{LC}_{50}<\right.$ $12.5 \mu \mathrm{g} / \mathrm{ml})$. DIL-EA exhibited greater cytotoxicity against PC-3, MDA-MB 231 and MCF-7 cell lines $\left(\mathrm{IC}_{50}<3 \mu \mathrm{g} / \mathrm{ml}\right.$ in each case) as well as higher protein kinase inhibitory action (MIC: $25 \mu \mathrm{g} /$ disc) compared to DSL-EA. Leukemia induced in rats was affirmed by elevated serum levels of WBCs $\left(7.78 \pm 0.012\left(\times 10^{3}\right) / \mu \mathrm{l}\right)$, bilirubin $(7.56 \pm 0.97 \mathrm{mg} / \mathrm{dl})$, Thiobarbituric acid reactive substances (TBARs) $(133.75 \pm 2.61 \mathrm{nM} / \mathrm{min} / \mathrm{mg}$ protein), decreased RBCs (4.33 \pm 0.065 $\left.\left(\times 10^{6}\right) / \mu \mathrm{l}\right)$, platelets $\left(344 \pm 3.19\left(\times 10^{3}\right) / \mu \mathrm{l}\right)$, total proteins $(2.14 \pm 0.11 \mathrm{~g} / \mathrm{dl})$, Glutathione S-transferases (GST) $(81.01 \pm 0.44 \mathrm{nM} / \mathrm{min} / \mathrm{ml})$, endogenous antioxidant enzymes levels and abnormal liver and kidney functionality in disease control rats. Both species revealed almost identical and significant $(p<0.05)$ alleviative effects in benzene induced leukemia.

\footnotetext{
* Correspondence: ihsn99@yahoo.com; ihaq@qau.edu.pk

'Department of Pharmacy, Faculty of Biological Sciences, Quaid-i-Azam University, Islamabad 45320, Pakistan

Full list of author information is available at the end of the article
}

(c) The Author(s). 2020 Open Access This article is licensed under a Creative Commons Attribution 4.0 International License, which permits use, sharing, adaptation, distribution and reproduction in any medium or format, as long as you give appropriate credit to the original author(s) and the source, provide a link to the Creative Commons licence, and indicate if changes were made. The images or other third party material in this article are included in the article's Creative Commons licence, unless indicated otherwise in a credit line to the material. If material is not included in the article's Creative Commons licence and your intended use is not permitted by statutory regulation or exceeds the permitted use, you will need to obtain permission directly from the copyright holder. To view a copy of this licence, visit http://creativecommons.org/licenses/by/4.0/. The Creative Commons Public Domain Dedication waiver (http://creativecommons.org/publicdomain/zero/1.0/) applies to the data made available in this article, unless otherwise stated in a credit line to the data. 
(Continued from previous page)

Conclusion: Comprehensive screening divulged the tremendous potential of selected species as potent source of natural anticancer agents in a variety of cancers particularly leukemia. Present study might provide useful finger prints in cancer research and mechanistic studies are prerequisite in logical hunt of this goal.

Keywords: Datura stramonium, Datura inoxia, Anticancer, Antileukemic, Breast cancer, Prostate cancer, Benzene toxicity

\section{Background}

Cancer is undoubtedly one of the leading causes of death worldwide. Global cancer statistics show that in males lung, prostrate and colon cancer are more common while in females breast, stomach, colon, rectum and ovarian cancers predominate [1]. Out of the many prominent causes of cancer, chemical carcinogens, inactivation of tumor suppressor genes, chromosomal rearrangements, impulsive transformations and viruses have played central roles in the onset of the disease $[2,3]$. Deviation from the normal process of DNA controlled cell division leads to cancer. Cell cycle process comprising of accurate DNA reproduction followed by production of ample organelles, cellular membranes and proteins for daughter cells and lastly, equal partition of cytoplasm and DNA during division must be monitored and looked after via a meticulous feedback control system. Any disorientation in the sequence of the aforementioned molecular steps leads to uncontrolled cell division and the onset of malignancy [3].

Normal cell is believed to transform into a cancerous cell after passing through numerous stages and the process may take several years or even decades to complete. Initiation, promotion and progression are the three important stages of carcinogenesis [4]. Averting initiation is an imperative strategy in anticancer therapy, likewise, curbing cancer in the stages following initiation. Oxidative damage to DNA is implicated as one of the major underlying mechanisms contributing to cancer. Division of cells carrying damaged DNA prior to its repair can lead to perpetual genetic alteration which is undoubtedly the initial step in carcinogenesis $[3,5]$.

The most commonly diagnosed and second leading cause of cancer related deaths in males is prostate cancer, while in females it is breast cancer. Notwithstanding the tireless efforts made to enhance their early diagnosis and treatment, an imperative need still exists for development of alternative therapeutic targets and new markers for effective management of both prostate and breast cancer patients [6, 7]. Women in both high and low resource settings are equally affected and it accounts for a major health burden worldwide [8]. It is a prime cause of death from cancers in women with over 1.1 million diagnosed cases and more than 410,000 deaths worldwide [9]. Furthermore, leukemia is a type of cancer that starts in the bone marrow, but in most cases quickly moves into the blood. The exact cause of leukemia is still unknown. Viral, genetic, environmental or immunological factors may be involved [10]. It is globally recognized as one of the deadliest cancer type in people of every age and ethnicity, so great efforts are made in pursuit of curative strategies against this deadly disease [11]. Abovementioned cancer types are thus targeted in current study using relevant in vitro and in vivo models.

Unfortunately, advancements in understating the molecular mechanism of cancer are not going to bring down the unacceptably higher mortality rates, unless and until the role of natural products in chemoprevention is revisited and revitalized. A large number of compounds used currently for cancer treatment and prevention are derived from natural sources including plants, animals and microorganisms. Plant based anticancer agents including, but not limited to vincristine, vinblastine, irinotecan, etoposide, paclitaxel etc. have served a great purpose in cancer therapeutics $[3,12]$.

Genus Datura (family Solanaceae) consists of all the nightshades and numerous agricultural plants. This genus contains medicinally important species, the most important ones being $D$. stramonium, $D$. inoxia, $D$. metel, D. ferox, D. ceratocaula. It has global geographical distribution and can be found throughout America, Europe and Asia either as native or adventive plants, moreover, some species have also been reported in Africa and Australia. Datura species have been used for their medicinal and recreational purposes since antiquity. Most common ethnopharmacological and traditional uses of these plants include; anesthetic, hypnotic, sedative, expectorant, demulcent, antihemorrhoidal, antiasthmatic and antitumor [13]. These plants are known predominantly for their alkaloidal content, most important of which are the tropane alkaloids namely hyoscyamine, hyoscine and atropine. Datura is also acclaimed for presence of withanolides, which constitute a large family of plant steroids and steroidal glycosides $[14,15]$.

$D$. inoxia Mill. and D. stramonium Linn. are the two species selected to carry out this research based on their ethnomedicinal properties and their incomplete appraisal as potential anticancer agents. Nonetheless, there is evidence to suggest their potential as sources of anticancer compounds. D. inoxia was found to be the most potent source of antioxidants when equated with other 
species of Datura in a comparative analysis of their free radical scavenging property towards 2, 2-diphenyl-1picrylhydrazyl (DPPH) a stable free radical [16]. Anticancer effects were also studied against human colon adenocarcinoma and larynx cancer cell lines and satisfactory results were observed. Likewise, dinoxin B, a withanolide recently isolated from $D$. inoxia, demonstrated significant anticancer activity when tested against several human cancer cell lines [14]. There are few studies regarding the anticancer potential of $D$. stramonium and it has shown noteworthy in vitro antioxidant and anticancer activity against the tested cancer cell lines [17, 18].

This work describes our findings in relation to the potential usage of extracts of $D$. inoxia and $D$. stramonium against kinase inhibitory, cytotoxicity against Artemia salina, normal human lymphocytes, cancer cell lines and in vivo antileukemic action of the two designated species and correlates the observed activities to estimated phytochemicals and the already reported secondary metabolites. Antileukemic action was evaluated using benzene induced leukemia model in male Sprague Dawley rats in an effort to associate the in vitro findings with potential anticancer effects of selected samples in relevant in vivo model.

\section{Methods}

\section{Plant collection and preparation of extract}

D. inoxia was collected from Quaid-i-Azam University, Islamabad Capital Territory, Pakistan, while D. stramonium was collected from Oghi town in dictrict Mansehra, Khyber Pakhtunkhwa, Pakistan in august 2016. D. stramonium was collected from its wild natural habitat and is not an endangered species thus no permission was required from any state agency. The collected plants were identified by Prof. Dr. Rizwana Aleem Qureshi, Department of Plant Sciences, Faculty of Biological Sciences, Quaid-i-Azam University Islamabad, Pakistan. Dried sample of both plants were deposited at the Herbarium of Quaid-i-Azam University, Islamabad, with voucher numbers PHM-487 for D. inoxia and PHM-504 for D. stramonium. Collected plants were washed with water. Leaf, fruit, steam and root parts were separated and shade dried at ambient temperature with adequate ventilation until fully dried out. Drying was followed by grinding the segregated plant parts into fine powder. Successive extraction at room temperature by ultra-sonication aided maceration was performed using n-hexane, ethyl acetate, methanol and distilled water as solvents. The process of extraction was repeated twice with each solvent and extracts were filtered using Whatmann No.1 filter paper. Extracts were latter concentrated in a rotary evaporator and dried in vacuum oven at $40{ }^{\circ} \mathrm{C}$. Samples of different concentrations were prepared and numerous bench top assays were performed in triplicate. Percent extract recovery (\%w/w) was calculated using the following formula;

$$
\% \text { Extract recovery }=\frac{A}{B} \times 100
$$

Where $\mathrm{A}=$ weight of dry extract and $\mathrm{B}=$ weight of powdered plant material.

\section{Chemicals and reagents}

All chemicals and reagents used in current study were of analytical grade. Solvents i.e. n-hexane, ethyl acetate, methanol and dimethylsulfoxide (DMSO) were purchased from Merck (Darmstadt, Germany). FolinCiocalteu reagent and DPPH were purchased from Sigma-Aldrich (Steinheim, Germany). Potassium dihydrogen phosphate, dipotassium hydrogen phosphate, ferrous chloride, sodium hydroxide, aluminum chloride, ascorbic acid, quercetin, gallic acid, rutin, caffeic acid, kaempferol, myricetin and (+)-catechin were acquired from Sigma-Aldrich (Steinheim, Germany). Tween 80, thiobarbituric acid, tricholoroacetic acid, ferric chloride and phenazine methosulphate were acquired from Sigma (Chemicals Co. St. Louis, USA). Sodium carbonate, sulphuric acid, hydrogen peroxide, potassium ferricyanide, sodium dihydrogen phosphate and disodium hydrogen phosphate were purchased from Merck KGaA (Darmstadt, Germany).

\section{Animals}

Brine shrimp eggs were acquired from Oceans Star International USA $\left(\mathrm{O} . S . \mathrm{I}^{\circ}\right)$. Sprague Dawley rats were purchased from National Institute of Health, Islamabad, Pakistan (NIH).

\section{Phytochemical analysis \\ Total phenolic content estimation (TPC)}

Standard procedure previously reported by Humaira et al., [19] was followed using Folin-Ciocalteu reagent for the determination of TPC. A stock solution $(4 \mathrm{mg} / \mathrm{ml})$ of each test sample was prepared in DMSO and an aliquot of $20 \mu \mathrm{l}$ from the stock solution was transferred to respective wells of a 96 well plate. It was followed by addition of $90 \mu \mathrm{l}$ of Folin-Ciocalteu reagent. After incubation at room temperature for $5 \mathrm{~min}, 90 \mu \mathrm{l}$ of sodium carbonate was added to wells carrying the reaction mixture. Absorbance was measured at $630 \mathrm{~nm}$ using microplate reader (Elx 800, Biotech USA). The experiment was run in triplicate and a calibration curve $\left(\mathrm{y}=0.0567 \mathrm{x}-0.0405, \mathrm{R}^{2}=0.9927\right)$ was drawn using gallic acid $(2.5,5,10,20,40 \mu \mathrm{g} / \mathrm{ml})$ as positive control under identical operating conditions. Estimated TPC was expressed as $\mu \mathrm{g}$ gallic acid equivalent per $\mathrm{mg}$ extract ( $\mu \mathrm{g}$ GAE/mg extract). 


\section{Total flavonoid content estimation (TFC)}

Aluminum chloride base calorimetric method was used for the estimation of TFC [20]. The assay was executed in 96 well plate and $20 \mu \mathrm{l}$ of test samples $(4 \mathrm{mg} / \mathrm{ml}$ DMSO) were transferred to the wells. It was followed by addition of $10 \mu \mathrm{l}$ each of $10 \%$ (w/v) aluminum chloride, $1.0 \mathrm{M}$ potassium acetate and $160 \mu \mathrm{l}$ of distilled water. Following incubation for $30 \mathrm{~min}$ at room temperature, absorbance of reaction mixture was taken at $415 \mathrm{~nm}$ using microplate reader. The experiment was run in triplicate and calibration curve $(y=0.0389 x-0.0187$, $\left.\mathrm{R}^{2}=0.9948\right)$ was drawn using quercetin as positive control $(2.5,5,10,20,40 \mu \mathrm{g} / \mathrm{ml})$. Ensuing TFC was expressed as $\mu \mathrm{g}$ quercetin equivalent per mg extract $(\mu \mathrm{g}$ $\mathrm{QE} / \mathrm{mg}$ extract).

\section{High performance liquid chromatography (HPLC) analysis}

The detection and quantification of polyphenols was performed by HPLC analysis of selected Datura species. Previously reported procedure by Bakht et al., [20] was followed with slight modifications as per system suitability. HPLC system, Agilent Chem station Rev. B.02-01-SR1 (260) was equipped with a Zorbex-C8 analytical column $(4.6 \times 250 \mathrm{~nm}, 5 \mu \mathrm{m}$ particle size $)$ in combination with a diode array detector (DAD; Agilent technologies, Germany). RP-HPLC analysis was carried out by using two mobile phases (A: acetonitrile:methanol:water: acetic acid in ratio 5:10:85:1 and $\mathrm{B}$ : acetonitrile: methanol:acetic acid in ratio 40:60:1) with a flow rate maintained at $1 \mathrm{ml} / \mathrm{min}$. The gradient (A: B) employed was: $0-20 \mathrm{~min}(0-50 \% \mathrm{~B}), 20-25 \mathrm{~min}(50-100 \% \mathrm{~B})$ and from 25 to $30 \mathrm{~min}$ it was $100 \% \mathrm{~B}$. Volume of sample (10 $\mathrm{mg} / \mathrm{ml}$ extracts) injected via an injection port into the column was $20 \mu \mathrm{l}$. Samples were filtered through a $0.45 \mu \mathrm{m}$ membrane filter prior to injection and each sample run was followed by a $10 \mathrm{~min}$ column reconditioning step. Wavelengths used to detect the standards were $257 \mathrm{~nm}$ for Rutin, $279 \mathrm{~nm}$ for gallic acid and catechin, $325 \mathrm{~nm}$ for caffeic acid and apigenin, while quercetin, myricetin and kaempferol were analyzed at $368 \mathrm{~nm}$. Identification and quantification of different polyphenols was accomplished by comparing the UV absorption spectra and retention time of samples with those of standards and the results were expressed as $\mu \mathrm{g} / \mathrm{mg}$ extract.

\section{Estimation of in vitro antioxidant potential \\ Determination of total antioxidant capacity (TAC)}

Total antioxidant capacity of extracts was determined by phosphomolybdenum based method described previously [21]. The assay was performed by mixing $100 \mu \mathrm{l}$ of extracts $(4 \mathrm{mg} / \mathrm{ml} \mathrm{DMSO})$ with a reagent solution consisting of $28 \mathrm{mM}$ sodium phosphate, $4 \mathrm{mM}$ ammonium molybdate and $0.6 \mathrm{M}$ sulphuric acid. Reaction mixture was then incubated at $95^{\circ} \mathrm{C}$ for $90 \mathrm{~min}$ followed by cooling at room temperature. Absorbance was estimated at $695 \mathrm{~nm}$ using a microplate reader. The assay was executed in triplicate, ascorbic acid was used a positive control and calibration curve was drawn $(y=0.0096 x+$ $\left.0.1538, R^{2}=0.9972\right)$. Negative control used in the experiment was DMSO and results were expressed as $\mu \mathrm{g}$ ascorbic acid equivalent (AAE) per mg extract.

\section{Determination of total reducing power (TRP)}

Extracts of selected Datura species were assessed for their reducing power by slight modification of previously reported protocol [22]. Briefly, $200 \mu \mathrm{l}$ of extracts $(4 \mathrm{mg} / \mathrm{ml}$ DMSO) were mixed with $400 \mu$ l each of phosphate buffer $(0.2 \mathrm{M}, \mathrm{pH} 6.6)$ and $1 \% \mathrm{w} / \mathrm{v}$ potassium ferricyanide [K3Fe (CN)6] and the mixture was incubated at $30^{\circ} \mathrm{C}$ for $50 \mathrm{~min}$. Trichloroacetic acid $(400 \mu \mathrm{l}$ of $10 \% \mathrm{w} / \mathrm{v}$ solution) was added to the mixture followed by centrifugation at 3000 rpm for $10 \mathrm{~min}$ at room temperature. Supernatant was collected and $150 \mu \mathrm{l}$ of it was transferred to wells of a 96 well microplate. Finally, $\mathrm{FeCl}_{3}(50 \mu \mathrm{l}$ of $0.1 \%$ w/v solution) was added to the corresponding wells and absorbance was measured at $700 \mathrm{~nm}$. DMSO was used as negative control while ascorbic acid served as positive control at 6.25$100 \mu \mathrm{g} / \mathrm{ml}$ final concentration and calibration curve was drawn $\left(y=0.0254 x-0.0543, R^{2}=0.9908\right)$. Estimated TRP was expressed as $\mu \mathrm{g}$ ascorbic acid equivalent (AAE) per mg extract.

\section{DPPH free radical scavenging assay}

Free radical scavenging potential of Datura extracts was evaluated by determining their ability to quench the stable 2, 2-diphenyl 1-picrylhydrazyl (DPPH) free radical [19]. The assay was performed in a 96 well plate and any discoloration of the purple colored DPPH solution indicated radical scavenging activity. An aliquot of extracts (20 $\mu \mathrm{l}$ from $4 \mathrm{mg} / \mathrm{ml}$ DMSO stock solution) was poured in respective wells of the 96 well plate followed by addition of $180 \mu \mathrm{l}$ of DPPH solution to make the final volume and concentration equal to $200 \mu \mathrm{l}$ and $400 \mu \mathrm{g} / \mathrm{ml}$ respectively. Positive control used in the assay was ascorbic acid $(1 \mathrm{mg} / \mathrm{ml})$ while DMSO was employed as a negative control. Following $30 \mathrm{~min}$ incubation at $37^{\circ} \mathrm{C}$, change in color was noted and absorbance was measured at $517 \mathrm{~nm}$. Decline in absorbance of the reaction mixture manifest the free radical scavenging potential of extracts. Percent scavenging activity was determined by using the following formula:

$$
\% R S A=1-\frac{\text { OD of sample }}{\text { OD of negative control }} \times 100
$$

Where OD stands for optical density. 
Samples which showed greater than $50 \%$ inhibition at $400 \mu \mathrm{g} / \mathrm{ml}$ were tested at lower concentrations and their $\mathrm{IC}_{50}$ values were estimated.

\section{In vitro cytotoxic assays Brine shrimp lethality assay}

Lethality of test samples against larvae of brine shrimps (Artemia salina) was evaluated in 96 well plate format following a previously reported protocol [23]. Simulated sea water (sea salt; $38 \mathrm{~g} / \mathrm{l}$ supplemented with $6 \mathrm{mg} / \mathrm{l}$ dried yeast) was prepared and Artemia salina eggs (Ocean 90, USA) were kept therein for a period of 24$48 \mathrm{~h}$ with proper oxygen supply allowing them to hatch. Specifically designed perforated plastic tray was used having two compartments. Sources of illumination and warmth $\left(30-32{ }^{\circ} \mathrm{C}\right)$ were also ensured. Phototropic nauplii were then shifted to respective wells of a 96 well plate. The cytotoxic activity of test samples was screened initially at 200, 100 and $50 \mu \mathrm{g} / \mathrm{ml}$ final concentration by transferring predetermined volume of extracts $(20 \mathrm{mg} / \mathrm{ml}$ stock solution) to wells containing shrimps larvae and sea water. Doxorubicin $(4 \mathrm{mg} / \mathrm{ml})$ was used as a positive control while DMSO was the negative control. Following a $24 \mathrm{~h}$ incubation period, lethality of test samples were estimated by observing the number of surviving shrimps. Samples showing greater than $50 \%$ mortality were tested at lower concentrations and median lethal concentration $\left(\mathrm{LC}_{50}\right)$ was calculated using table curve $2 \mathrm{D}$ v5.01 software. Surviving shrimps after completion of assay were treated with $6 \%$ sodium hypochlorite solution for 1 hour and disposed of in the septic tank. Surplus untested shrimps were used as fish food in dedicated fish pond at the University campus.

\section{Protein kinase inhibition assay}

Stremtomyces $85 \mathrm{E}$ was used as a test strain in the execution of this assay following an already reported protocol [24]. Spores of test strain were inoculated in sterile trypton soya broth (TSB). Incubation at $37^{\circ} \mathrm{C}$ for $24 \mathrm{~h}$ was followed by turbidity adjustment as per McFarland 0.5 turbidity standard using sterile TSB. Petri plates with minimal ISP4 medium were seeded with inoculum of Stremtomyces $(100 \mu \mathrm{l})$. Sterile filter paper discs impregnated with extracts of selected Datura species $(5 \mu \mathrm{l}$ from $20 \mathrm{mg} / \mathrm{ml}$ DMSO stock solution) were positioned on the seeded agar plates. Positive and negative controls used were surfactin and DMSO respectively. Plates were incubated at $28^{\circ} \mathrm{C}$ for a duration sufficient enough to allow hyphae formation (up to $72 \mathrm{~h}$ ). Appearance of bald zone around the discs showed that extracts have inhibited spores and mycelia formation. Results were interpreted by measuring diameter of inhibitory zones to the nearest $\mathrm{mm}$.

\section{Cytotoxicity against cell lines}

In vitro cytotoxicity of extracts against PC-3 (ATCC CRL-1435), MDA-MB 231 (ATCC\# HTB-26 ${ }^{\mathrm{TM}}$ ) and MCF7 (ATCC\# HTB-22 $2^{\mathrm{im}}$ ) cancer cell lines was assessed by following an already reported protocol [23]. Selected cancer cell lines were grown in RPMI-1640 growth medium buffered with $2.2 \mathrm{~g} / \mathrm{l} \mathrm{NaHCO}_{3}$ and supplemented with $10 \% \mathrm{v} /$ $\mathrm{v}$ heat inactivated foetal bovine serum (HIFBS) having $\mathrm{pH}$ 7.4. Cells were grown and kept in a humidified $\mathrm{CO}_{2}(5 \%)$ incubator at $37^{\circ} \mathrm{C}$. Extracts were tested at a final concentration of $20 \mu \mathrm{g} / \mathrm{ml}$ by adding $10 \mu \mathrm{l}$ from the stock solution (dissolved in 1\% DMSO in PBS) to wells of 96 well plate. Afterwards, $190 \mu \mathrm{l}$ of cell suspension (seeding density of $1 \times 10^{4}$ cells $/ \mathrm{ml}$ ) was transferred to respective wells. The 96 well plate was then kept in humidified $\mathrm{CO}_{2}$ (5\%) incubator at $37^{\circ} \mathrm{C}$ for a period of $72 \mathrm{~h}$. It was followed by addition of $20 \mu \mathrm{l}$ of pre-filter sterilized MTT solution (4 $\mathrm{mg} / \mathrm{ml}$ in distilled $\mathrm{H}_{2} \mathrm{O}$ ) to the wells and re-incubation at $37^{\circ} \mathrm{C}$ for $4 \mathrm{~h}$ in identical conditions. Afterwards, a multichannel pipette was used for careful removal of supernatant from the wells without unsettling the colored formazan sediments. These sediments were then dissolved by addition of $100 \mu \mathrm{l}$ of DMSO to each well and complete dissolution was ensured by keeping the plate aside for $1 \mathrm{~h}$. Absorbance was measured at $540 \mathrm{~nm}$ using microplate reader. Doxorubicin was used a positive control while $1 \%$ DMSO in PBS was the negative control used in current study. Extracts that showed greater than 50\% cell death at $20 \mu \mathrm{g} / \mathrm{ml}$ were analyzed at lower concentrations (10, 5, 2.5 and $1.25 \mu \mathrm{g} / \mathrm{ml}$ ) and their $\mathrm{IC}_{50}$ values were calculated using table curve 2D v5.01 software. The experiment was run in triplicate.

Out of 32 crude extracts in four different solvents, ethyl acetate leaf extracts of D. stramonium (DSL-EA) and $D$. inoxia (DIL-EA) were selected for estimation of in vivo antileukmic activity. Extracts were standardized on the basis of their significant phenolics and flavonoids content as well as noteworthy antioxidant, protein kinase inhibitory and cytotoxic potential.

\section{Animal model}

Fifty four (54) male Sprague Dawley rats aged 6-8 weeks weighing in range of $\sim 150-250 \mathrm{~g}$ were used in current study. The animals were kept in aluminum cages with wood shavings as bedding at $25 \pm 1^{\circ} \mathrm{C}$ and air humidity of $45 \pm 5 \%$ with a $12 \mathrm{~h}$ light/dark cycle. The bedding was changed regularly to avoid any infection and health hazards to study animals. Rats were provided standard laboratory feed and water ad libitum preceding their use in experiments.

\section{Experimental protocol}

After a 1 week acclimatization period, rats were divided randomly into nine groups, each group consisting of six 
rats. Predetermined doses (high dose; HD and low dose; LD) of DSL-EA, DIL-EA extracts as well as standard drug dissolved in 10\% DMSO, were administered orally using sterilized disposable oral gavage to specified groups. Total volume to be given orally was kept constant at $1 \mathrm{ml}$. Three controls were included in the study i.e. vehicle, disease and positive control groups. Treatments were given in the morning on alternate days.

Group I: Vehicle control (10\% DMSO in water).

Group II: Disease control $(0.2 \mathrm{ml}$ Benzene, 1:10 in water for injection).

Group III: Positive control (Cyclophosphamide $10 \mathrm{mg} / \mathrm{kg}$ ).

Group IV: DSL-LD (100 mg/kg, Preventive).

Group V: DSL-HD (200 mg/kg, Preventive).

Group VI: DIL-LD (100 mg/kg, Preventive).

Group VII: DIL-HD (200 mg/kg, Preventive).

Group VIII: DSL-HD (200 mg/kg, Treatment).

Group IX: DIL-HD (200 mg/kg, Treatment).

The duration of the in vivo study was 30 days and groups in preventive mode (Group IV-VII) were orally administered with doses of Datura extracts starting from day one of experiment (15 doses). On the contrary, treatment groups (Group VIII and IX) received high doses of extracts after leukemia was induced in rats (7 doses). The details of study design and procedure are given in the schematic diagram Fig. 1.

\section{Animal ethical statement}

The guidelines approved by the ethical committee of Quaid-i-Azam University, Islamabad, Pakistan (Letter No. QAU-PHM-023/2016 for experimentation and Letter No. QAU-PHM-017/2016 for the animal care) were strictly followed throughout the experiment. Blood sampling from healthy volunteers was also approved by review board of Quaid-i-Azam University (Letter No. IRB-QAU-116; Dated 4/11/2016). It was assured that the animals used in the study were handled with minimum possible discomfort, pain and distress by provision of appropriate analgesia, sedation and anesthesia. Animal/human use was also meant to offer insights and new information for the wellbeing of humans/animals.

\section{Toxicity assessment}

\section{In vitro toxicity testing by using isolated lymphocytes}

Lymphocytes were isolated from human blood following a procedure reported earlier with modifications made as per system suitability [25]. A written informed consent was obtained from the participant. Blood $(3 \mathrm{ml})$ was taken through venipuncture from a healthy donor and diluted with an equal portion of PBS. The diluted blood sample was layered over $2 \mathrm{ml}$ Histopaque-1077 and centrifuged at $800 \times \mathrm{g}$ for $20 \mathrm{~min}$. The buffy coat was then aspirated into PBS $(5 \mathrm{ml})$ and lymphocytes pellet was obtained by centrifugation at $350 \mathrm{rpm}$ for $4 \mathrm{~min}$. The

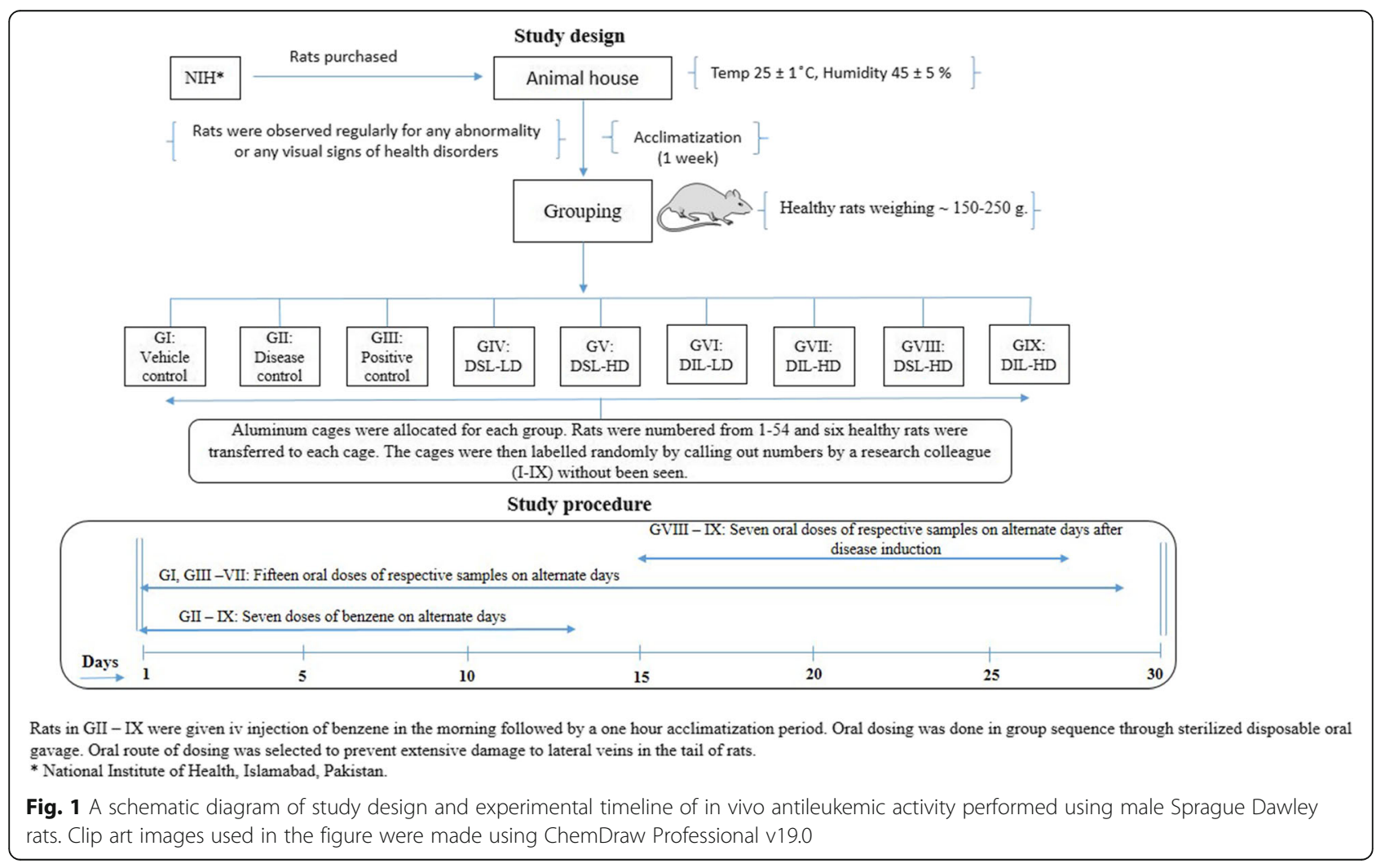


pellet acquired was suspended in RPMI-1640 (1 ml) and cell density was adjusted to $1 \times 10^{5}$ cells $/ \mathrm{ml}$. Cytotoxicity was determined by incubating $20 \mu \mathrm{l}$ of extracts $(20 \mu \mathrm{g} /$ $\mathrm{ml}$ ) along with $180 \mu \mathrm{l}$ of lymphocyte suspension at $37^{\circ} \mathrm{C}$ for $24 \mathrm{~h}$ in a 96 well plate. Humidified carbon dioxide (5\%) incubator was used for incubation. Lymphocyte growth was stimulated by addition of phytohaemagglutinin (PHA) in the medium. Following the predetermined time period, MTT assay was performed as discussed above and percent mortality was calculated using the following formula:

$$
\text { \%cytotoxicity }=\left[100-\left(\frac{A s}{A c} \times 100\right)\right]
$$

Where, As and Ac denote absorbance of sample and negative control respectively.

\section{In vivo acute toxicity in rats}

Acute toxicity assay was performed in rats divided randomly into test and control groups $(n=6)$. Rats in the test groups were orally administered with increasing doses of test samples $(150,300,500,1000$ and $2000 \mathrm{mg} /$ $\mathrm{kg}$ ). Single booster dose of the mentioned strengths were given to respective groups while rats in the control group were given normal saline $(10 \mathrm{ml} / \mathrm{kg}$ of animals). Animals were observed daily for a period of two weeks and mortality rates as well as toxic symptoms were noted. Any aberrations in behavioral pattern i.e. balance, aggression and sleep; body secretions i.e. lacrimation, salivation, nasal discharge, urination and defecation, as well as visual signs of any injury to different organs were closely monitored. Guidelines provided by Organization for Economic Cooperation and Development (OECD) were followed and ensured during acute toxicity study.

\section{In vivo antileukemic assay in rats}

\section{Benzene induced leukemia in rats}

Rats used for the assay were divided randomly into 9 groups as described earlier and benzene model was adopted for leukemia induction [11, 26, 27]. Benzene $(0.2 \mathrm{ml})$ was injected in the lateral tail vein after restraining the rat in a physical restrainer and keeping its tail in warm water $\left(45^{\circ} \mathrm{C}\right)$. Benzene was administered on alternate days for 2 weeks. Rats were observed for any visible signs of disease induction i.e. excessive bruising, unusual bleeding, dark colored urine, labored and/or rapid breathing, increased heart rate, fatigue, weakness, petechiae and skin rashes.

\section{Collection of blood samples and separation of serum}

Rats were anesthetized at the end of the assay by chloroform inhalation, euthanized using cervical dislocation and blood was drawn from abdominal aorta of each rat for assessment of primary outcomes like hematological effects as well as secondary outcomes including relevant biochemical and serological findings. Centrifugation of blood samples at $6000 \mathrm{rpm}$ (for $15 \mathrm{~min}$ at $4{ }^{\circ} \mathrm{C}$ ) was performed for separation of serum. Serum was kept at $20^{\circ} \mathrm{C}$ until analyzed.

\section{Haematological studies}

These involved the estimation of red blood cell (RBC), white blood cell (WBC) and platelet count with the help of neubauer haemocytometer (Feinoptik, Germany). Erythrocyte sedimentation rate (ESR) was estimated following Westergren method [28], while hemoglobin $(\mathrm{Hb})$ content was determined by Sahli's haemoglobin meter.

\section{Determination of biochemical parameters}

Sera of experimental rats was analyzed for numerous biochemical parameters i.e. alanine transaminase (ALT), aspartate aminotransferase (AST), alkaline phosphatase (ALP), creatinine phosphokinase (CPK), total serum protein, urea and creatinine using standard AMP diagnostic kits (Stattogger Strasse 31b 8045 Graz, Austria) while Bradford method was followed for the determination of protein concentration [29].

\section{Determination of endogenous antioxidant enzymes}

For the assessment of endogenous antioxidant enzymes i.e. catalase $(\mathrm{CAT})$, peroxidase $(\mathrm{POD})$, superoxide dismutase (SOD) and glutathione S-transferase (GST), serum separated from the blood of rats was used and an already reported protocol [30] was followed with slight modifications as per system suitability.

\section{Expression of TBARs and NO}

Level of Thiobarbituric acid reactive substances (TBARs) in serum was estimated by TBARs assay using a slightly modified version of an already described procedure [30].

Nitric oxide (NO) levels were calculated using procedure described by Grisham et al., [31]. Following a slightly modified protocol, serum $(50 \mu \mathrm{l})$ was mixed with equal portions of $0.3 \mathrm{M} \mathrm{NaOH}$ and $5 \% \mathrm{ZnSO}$. Centrifugation was performed at $6400 \times \mathrm{g}$ for $15-20 \mathrm{~min}$. Supernatant $(30 \mu \mathrm{l})$ was collected, transferred to 96 well plate and mixed with $200 \mu \mathrm{l}$ of Griess reagent. Absorbance was recorded at $540 \mathrm{~nm}$. Sodium nitrite curve $(\mathrm{y}=0.0015 \mathrm{x}+$ $\left.0.002, R^{2}=0.9821\right)$ was drawn under identical conditions to estimate serum nitrite level.

\section{Histological investigation}

Paraffin embedded staining procedure was employed for evaluation of any changes in normal histology. Dissected tissues of liver and kidney were fixed with the help of buffered formaldehyde (10\%, $\mathrm{pH} 7.4)$ at room temperature for a period of $12 \mathrm{~h}$. Fixed tissues were washed repeatedly 
with ethanol (50, 70, 90 and 100\%) to remove any traces of infiltrated wax and water. Slides were prepared by sectioning small pieces (3-5 $\mu \mathrm{m}$ thickness) of the embedded tissue samples which were then stained with Eosin [31] and Haematoxylin. Subsequently, slides were examined under Nikon Microscope (Eclipse 80i, Japan).

\section{Percent alleviative effects of Datura extracts in benzene induced leukemia}

Antileukemic potential of both species was evaluated by determining the alleviative effects in comparison to the disease control group which did not receive any treatment. Percent antileukemic effects produced by Datura species were statistically compared with the results procured in case of positive control group. Percent alleviating/antileukemic potential was evaluated by using the following formula:

$$
\begin{aligned}
& \text { \%Alleviating effects } \\
& \qquad=\frac{\text { average sample values }- \text { average disease control values }}{\text { average disease control values }} \times 100
\end{aligned}
$$

\section{Statistical analysis}

The data presented in this study was procured from experiments performed in triplicate and values are presented as mean \pm SD. Variability amongst groups was determined by performing one way analysis of variance using Statistix 8.1. Tukey's multiple comparison and Kruskal-Wallis tests were performed to calculate significant differences among test groups. Statistical significance was set at $p<0.05$.

\section{Results}

Ethyl acetate leaf extracts of D. stramonium (DSL-EA) and D. inoxia (DIL-EA) were selected based on proficient results in preliminary in vitro screening assays.

\section{Percent extract recovery}

Percent extract recovery in case of DSL-EA extract was $2.33 \%$ while it was $2.59 \%$ in case of DIL-EA extract.

\section{Phytochemical investigation \\ Total phenolic and flavonoid content}

Phenolic and flavonoid content of EA leaf extracts of both plants was estimated. TPC estimated in DSL-EA was $28.67 \pm 0.97$, while in case of DIL-EA it was $27.69 \pm$ $1.12 \mu \mathrm{g}$ GAE/mg extract. Quercetin equivalent flavonoid content estimated in DSL-EA was $16.16 \pm 0.06$ and in DIL-EA the content was $20.17 \pm 0.17 \mu \mathrm{g} \mathrm{QE} / \mathrm{mg}$ extract as presented inTable 1.

\section{RP HPLC analysis}

Quantification of selected plant phenolics was accomplished with the aid of reverse phase HPLC-DAD based
Table 1 Total phenolic and flavonoid content of EA leaf extracts of D.stramonium and D.inoxia

\begin{tabular}{lll}
\hline Samples & TPC $(\mu \mathrm{g}$ GAE $/ \mathrm{mg}$ extract $)$ & TFC $(\mu \mathrm{g}$ QE/mg extract $)$ \\
\hline DSL-EA & $28.67 \pm 0.97$ & $16.16 \pm 0.06$ \\
DIL-EA & $27.69 \pm 1.12$ & $20.17 \pm 0.17$ \\
\hline
\end{tabular}

profiling. Retention time and UV spectra of extracts were compared with reference standards. Figure 2 and Additional file 1-3. Rutin, gallic acid, catechin, apigenin and caffeic acid were quantified in the tested extracts. In DSLEA extract rutin $(0.89 \pm 0.025 \mu \mathrm{g} / \mathrm{mg}$ extract $)$, gallic acid $(0.35 \pm 0.072 \mu \mathrm{g} / \mathrm{mg}$ extract $)$, catechin $(0.24 \pm 0.023 \mu \mathrm{g} / \mathrm{mg}$ extract) and apigenin $(0.29 \pm 0.091 \mu \mathrm{g} / \mathrm{mg}$ extract $)$ were detected. Rutin $(0.036 \pm 0.004)$ and caffeic acid $(0.27 \pm$ $0.031 \mu \mathrm{g} / \mathrm{mg}$ extract) was quantified in DIL-EA. (Table 2).

\section{In vitro antioxidant potential}

\section{Total antioxidant capacity and total reducing power}

The total antioxidant capacity of extracts was appraised using phosphomolybdenum based method and results were expressed as ascorbic acid equivalent (AAE). TAC exhibited by DSL-EA was $160.92 \pm 3.00 \mu \mathrm{g}$ AAE/mg extract, while in case of DIL-EA it was $140.44 \pm 5.6 \mu \mathrm{g}$ AAE/mg extract (Table 3).

TRP was manifested by evaluating the ferric ion $\left(\mathrm{Fe}^{3+}\right)$ conversion to ferrous ion $\left(\mathrm{Fe}^{2+}\right)$ in the presence of known concentration of extracts. Results indicated that reducing power depicted by DSL-EA was $50.43 \pm 1.72 \mu \mathrm{g}$ AAE/mg extract, while DIL-EA followed with $44.02 \pm$ $1.30 \mu \mathrm{g} \mathrm{AAE} / \mathrm{mg}$ extract (Table 3 ).

\section{DPPH scavenging assay}

Extracts were tested for their percent free radical scavenging activity (\% FRSA), both DSL-EA and DIL-EA did not show any appreciable scavenging potential as shown in Table 3.

\section{In vitro cytotoxicity assessment}

Brine shrimps cytotoxicity assay

Cytotoxicity profile was evaluated with the aid of brine shrimp lethality assay. Selected extracts of both Datura species showed remarkable activity. DSL-EA and DILEA showed significant results with $\mathrm{LC}_{50}$ values of $12.04 \pm 0.85$ and $10.37 \pm 1.56 \mu \mathrm{g} / \mathrm{ml}$ respectively. Doxorubicin was used as a standard and its $\mathrm{LC}_{50}$ value was recorded to be $5.43 \mu \mathrm{g} / \mathrm{ml}$. Results are shown in Table 4.

\section{Protein kinase inhibition assay}

The capability of extracts to inhibit protein kinase and subsequently the aerial hyphae formation by extracts was gauged on the basis of appearance of bald zones on cultured plates. DIL-EA showed significant inhibitory potential by exhibiting a $19 \mathrm{~mm}$ bald phenotype zone at 


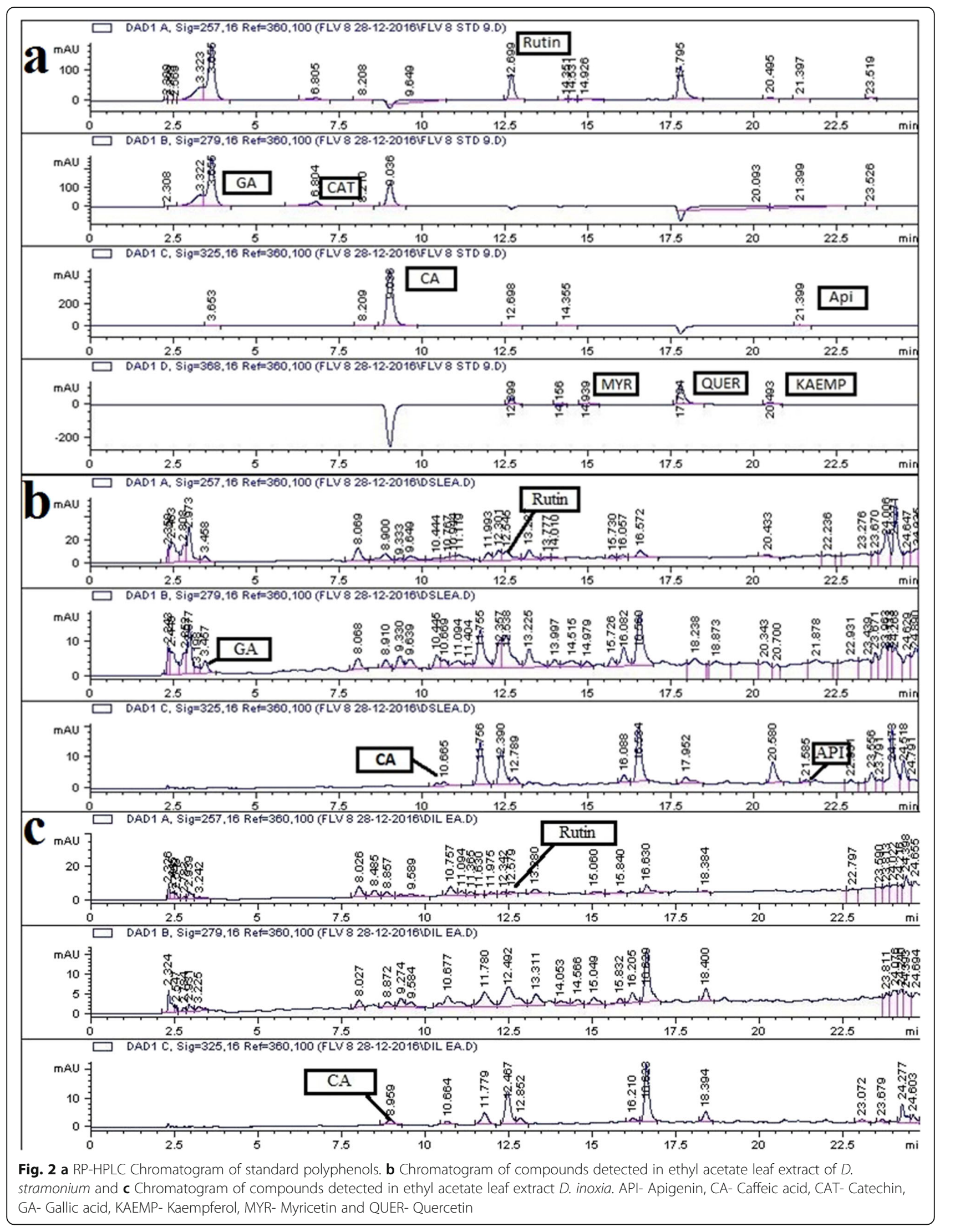


Table 2 Chemical profiling of EA leaf extracts of D.stramonium and D.inoxia using HPLC-DAD

\begin{tabular}{llll}
\hline Polyphenols & Signal wavelength & \multicolumn{2}{l}{ Quantity $(\mu \mathrm{g} / \mathrm{mg}$ extract $)$} \\
\cline { 3 - 4 } & & DSL-EA & DIL-EA \\
\hline Rutin & 257 & $0.89 \pm 0.03^{* * *}$ & $0.036 \pm 0.004^{*}$ \\
Gallic acid & 279 & $0.35 \pm 0.07^{* *}$ & - \\
Catechin & 279 & $0.24 \pm 0.02^{* *}$ & - \\
Caffeic acid & 325 & - & $0.27 \pm 0.03^{* *}$ \\
Apigenin & 325 & $0.29 \pm 0.09^{* *}$ & - \\
Myricetin & 368 & - & - \\
Quercetin & 368 & - & - \\
Kaempferol & 368 & - & - \\
\hline
\end{tabular}

$* * *=$ significant, ${ }^{* *}=$ fair, and ${ }^{*}=$ slight concentration

a concentration of $100 \mu \mathrm{g} /$ disc (MIC: $25 \mu \mathrm{g} /$ disc). Moreover, DSL-EA exhibited a bald zone of $12.50 \mathrm{~mm}$ at the same concentration (MIC: $100 \mu \mathrm{g} /$ disc). Surfactin been used as a positive control exhibited a $26.5 \mathrm{~mm}$ zone while DMSO (negative control) did not show any inhibitory potential. The results are demonstrated in Table 4.

\section{Cytotoxicity against cell lines}

Cytotoxicity against PC-3, MDA-MB 231 and MCF-7 was determined initially as percent inhibition at $20 \mu \mathrm{g} /$ $\mathrm{ml}$ final concentration followed by determination of $\mathrm{IC}_{50}$ values of potent extracts. Details are given in Table 4. The most promising activity was shown by DIL-EA against each cancer cell line with $\mathrm{IC}_{50}$ values of $2.86 \pm$ $0.1 \mu \mathrm{g} / \mathrm{ml}$ against PC-3, $1.56 \pm 0.16 \mu \mathrm{g} / \mathrm{ml}$ against MDAMB 231 and $2.45 \pm 0.04 \mu \mathrm{g} / \mathrm{ml}$ in case of MCF-7 cell line. DSL-EA showed mediocre cytotoxic potential with $14.34 \%$ inhibition against PC-3, 37.67\% in case of MDAMB 231 and 40.56\% against MCF-7 cell line. Doxorubicin was the positive control used and it exhibited $\mathrm{IC}_{50}$ values of $2.95 \pm 0.1, \quad 3.2 \pm 0.11$ and $2.45 \pm 0.24 \mu \mathrm{g} / \mathrm{ml}$ against PC-3, MDA-MB 231 and MCF-7 cell lines respectively.

\section{Toxicity studies}

\section{Lymphocyte toxicity assay}

Cytotoxic nature of selected extracts was also evaluated against normal lymphocytes isolated from human blood. Percent inhibition was calculated at $20 \mu \mathrm{g} / \mathrm{ml}$ final concentration (Table 4). No significant activity was depicted by either DSL-EA or DIL-EA against normal lymphocytes.
The cytotoxicity of DS-L-EA and DIL-EA was merely 4 and $23 \%$ respectively. Observed cytotoxicity was significantly $(p<0.05)$ lower in comparison to that observed against cancer cells. This selective action of used extracts is extremely beneficial in targeting cancerous cells while sparing the normal ones. Vincristine was used as a positive control and it exhibited an $\mathrm{IC}_{50}$ value of $6.98 \pm 0.19 \mu \mathrm{g} / \mathrm{ml}$.

\section{In vivo acute toxicity assay}

Acute toxicity was evaluated in rats at doses of 150$2000 \mathrm{mg} / \mathrm{kg}$. Close surveillance of rats during an observation period of 2 weeks showed that DSL-EA and DILEA had no lethal effects. There were no notable behavioral changes nor any deaths witnessed during the said period. Rats showed no visible signs of abnormalities in senses and any deviations from normal physiology. These findings showed that the chosen extracts were safe up to the highest dose of $2000 \mathrm{mg} / \mathrm{kg}$ and additional pharmacological studies can be safely undertaken within the specified range.

\section{In vivo antileukemic assay}

Following intravenous administration of predetermined doses of benzene to preventive, treatment and disease control groups, obvious signs of leukemia induction were observed including, unusual bleeding, excessive bruising, skin rashes, weakness and weight loss. Efficacy of extracts in treatment or prevention of disease progression was measured through a series of haematological, biochemical and histological studies.

\section{Benzene induced haematological variations}

Results of benzene induced haematological variations are displayed in Table 5. As evident from the data, the carcinogen used has caused a whole lot haematological aberrations, most eminent of which are decline in RBCs $\left(4.33 \pm 0.065 \times 10^{6} / \mu \mathrm{l}\right)$, platelets $\left(344 \pm 3.19 \times 10^{3} / \mu \mathrm{l}\right)$ and haemoglobin levels $(5.9 \pm 0.26 \mathrm{~g} / \mathrm{dl})$ while increase in ESR $(9.6 \pm 0.12 \mathrm{~mm} / \mathrm{h})$ and WBCs count $(7.78 \pm 0.012 \times$ $10^{3} / \mu \mathrm{l}$ ) was also observed in disease control rats. Findings of hematological investigation revealed that the positive control, vehicle control, preventive and treatment groups are significantly different $(p<0.05)$ from the disease control group. The average RBC and platelets count in preventive and treatment groups of both plant species were raised up to $5.78 \pm 0.23 \times 10^{6} / \mu \mathrm{l}$ and $529 \pm$ $20.17 \times 10^{3} / \mu \mathrm{l}$ respectively, while average haemoglobin

Table 3 In vitro antioxidant potential of EA leaf extracts of D.stramonium and D.inoxia

\begin{tabular}{llll}
\hline Samples & TAC $(\mu \mathrm{g} \mathrm{AAE} / \mathrm{mg}$ extract & TRP $(\mu \mathrm{g}$ AAE/mg extract & DPPH $(\%$ scavenging at 400 $\mu \mathrm{g} / \mathrm{ml})$ \\
\hline DSL-EA & $160.92 \pm 3.00$ & $50.43 \pm 1.72$ & $<50 \%$ \\
DIL-EA & $140.44 \pm 5.6$ & $44.02 \pm 1.30$ & $<50 \%$ \\
\hline
\end{tabular}




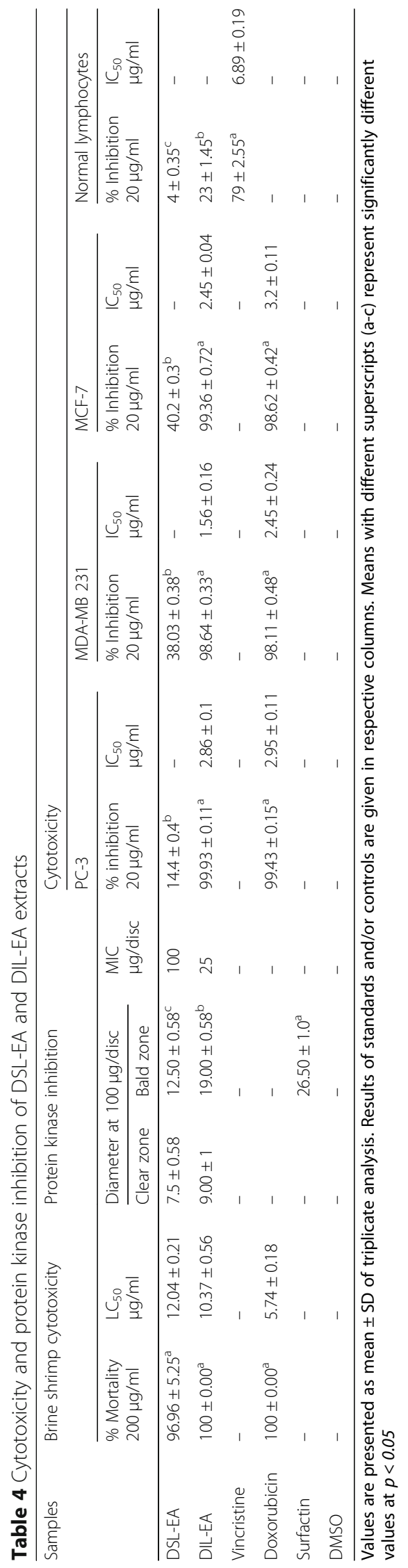


Table 5 Haematological investigations of experimental rats of all study groups

\begin{tabular}{|c|c|c|c|c|c|}
\hline Groups & $\operatorname{RBCs}\left(\times 10^{6}\right) / \mu \mathrm{l}$ & WBCs $\left(\times 10^{3}\right) / \mu \mathrm{l}$ & Platelets $\left(\times 10^{3}\right) / \mu$ l & $\mathrm{Hb}(\mathrm{g} / \mathrm{dl})$ & ESR $(\mathrm{mm} / \mathrm{h})$ \\
\hline Vehicle control & $6.23 \pm 0.035^{a}$ & $3.55 \pm 0.018^{f}$ & $581 \pm 2.72^{\mathrm{a}}$ & $9.78 \pm 0.62^{\mathrm{a}}$ & $4.4 \pm 0.067^{9}$ \\
\hline Positive control & $6.03 \pm 0.095^{a}$ & $3.85 \pm 0.067^{d}$ & $495 \pm 2.72^{e}$ & $8.38 \pm 0.62^{b}$ & $5.4 \pm 0.067^{f}$ \\
\hline Disease control & $4.33 \pm 0.065^{c}$ & $7.78 \pm 0.012^{\mathrm{a}}$ & $344 \pm 3.19^{f}$ & $5.9 \pm 0.26^{\mathrm{e}}$ & $9.6 \pm 0.12^{\mathrm{a}}$ \\
\hline DSL LD (P) & $5.73 \pm 0.071^{\mathrm{ab}}$ & $3.61 \pm 0.025^{\mathrm{de}}$ & $538 \pm 1.98^{c}$ & $7.7 \pm 0.35^{\mathrm{cd}}$ & $5.7 \pm 0.071^{e}$ \\
\hline DSL HD (P) & $5.95 \pm 0.083^{\mathrm{ab}}$ & $3.72 \pm 0.038^{\mathrm{de}}$ & $556 \pm 2.59^{b}$ & $7.7 \pm 0.47^{\mathrm{bc}}$ & $5.9 \pm 0.066^{d}$ \\
\hline DIL LD (P) & $5.86 \pm 0.037^{\mathrm{ab}}$ & $3.86 \pm 0.027^{d}$ & $523 \pm 3.07^{d}$ & $7.34 \pm 0.72^{c d}$ & $6.2 \pm 0.034^{c}$ \\
\hline DIL HD (P) & $6.02 \pm 0.065^{\mathrm{a}}$ & $4.01 \pm 0.011^{c}$ & $541 \pm 2.63^{c}$ & $7.12 \pm 0.58^{c d}$ & $6.12 \pm 0.081^{c}$ \\
\hline DSL HD (T) & $5.36 \pm 0.069^{b}$ & $4.23 \pm 0.044^{b}$ & $517 \pm 1.98^{d}$ & $7.2 \pm 0.28^{d}$ & $6.21 \pm 0.036^{c}$ \\
\hline DIL HD (T) & $5.73 \pm 0.081^{b}$ & $4.25 \pm 0.035^{b}$ & $499 \pm 2.94^{\mathrm{e}}$ & $7.52 \pm 0.79^{c d}$ & $6.34 \pm 0.097^{b}$ \\
\hline
\end{tabular}

Values are presented as mean \pm SD ( $n=6$, where $n=$ number of rats analysed in each group). Means with different superscripts (a-g) in the columns are significantly $(p<0.05)$ different from one another

levels were elevated to $7.43 \pm 0.25 \mathrm{~g} / \mathrm{dl}$. High and low doses of both species of Datura normalized the WBCs count and ESR with average values of $3.95 \pm 0.26 \times 10^{3}$ / $\mu \mathrm{l}$ and $6.08 \pm 0.24 \mathrm{~mm} / \mathrm{h}$ respectively.

\section{Determination of enzymatic and biochemical parameters}

Various enzymatic and biochemical tests performed on serum acquired from rats of study groups have clearly shown the deleterious effects of benzene on vital organs including liver and kidney in the disease control group. Administration of low and high doses of DSL-EA and DIL-EA have curbed the harm instigated by benzene to a great extent as evident from the enzymatic and biochemical findings of test groups. Liver enzymes and CPK levels of disease control group were significantly higher $(p<0.05)$ than all other groups. ALT, AST, ALP and CPK levels estimated in disease control rats were $93.02 \pm 2.64,67.80 \pm 2.05,356 \pm 5.69$ and $234 \pm 4.97 \mathrm{U} / \mathrm{L}$ respectively. Moreover, total proteins estimated in the serum were expressively lower in case of disease control rats (Albumin 1.20 \pm 0.07 , globulin $0.94 \pm 0.07$ and total protein $2.14 \pm 0.11 \mathrm{~g} / \mathrm{dl}$ ) confirming the harm caused to liver by benzene. Low and high doses of tested extracts have reverted the liver damage in identical manner, average values of ALT, AST, ALP, CPK and total proteins of 6 groups (both preventive and treatment) are; $41.56 \pm 2.59$, $27.99 \pm 1.98 .141 \pm 8.46,148.1 \pm 7.98 \mathrm{U} / \mathrm{L}$ and $6.54 \pm 0.38$ $\mathrm{g} / \mathrm{dl}$ respectively. The details are given in Tables 6 and 7 .

Creatinine, urea and bilirubin levels were markedly high in disease control rats confirming acute leukemic condition and kidney damage. High and low doses of selected plants have notably reversed the abuse inflicted by benzene as evident in Table 7. Statistically significant difference $(p<0.05)$ was observed when positive control and other groups were compared with disease control group.

\section{Endogenous antioxidant enzymes}

The activity level of endogenous antioxidant enzymes in serum is presented in Table 8. A significant $(p<0.05)$ decline in CAT, POD, SOD and GST was estimated in disease control group when compared with vehicle and positive control groups. Activity levels of CAT, POD, SOD and GST in serum drawn from disease control rats were $0.5 \pm 0.04,1.00 \pm 0.04 \mathrm{U} / \mathrm{min}, 0.96 \pm 0.05 \mathrm{U} / \mathrm{mg}$ protein and $81.01 \pm 0.44 \mathrm{nM} / \mathrm{min} / \mathrm{ml}$ respectively. A dose dependent increase in CAT, SOD, POD and GST level was observed in test groups. Significant $(p<0.05)$ increase was observed in case of high doses of selected plants in preventive and treatment groups. High doses of DIL raised the activity levels of CAT, POD, SOD and GST to a reasonably greater extent as compared to similar doses of DSL in treatment mode i.e. $2.5 \pm 0.15,3.9 \pm$ $0.10 \mathrm{U} / \mathrm{min}, 2.27 \pm 0.09 \mathrm{U} / \mathrm{mg}$ protein and $162.03 \pm 1.54$ $\mathrm{nM} / \mathrm{min} / \mathrm{ml}$ respectively. Low doses given to preventive groups showed slight increase in antioxidant enzymes and GST level.

\section{Expression of TBARs and NO}

After completion of the assay, TBARs and NO levels were recorded in serum obtained from test rats of each group. Benzene treated disease control group showed escalated level of TBARs i.e. $133.75 \pm 2.61 \mathrm{nM} / \mathrm{min} / \mathrm{mg}$

Table 6 Enzymatic investigation of control and leukemic rats

\begin{tabular}{lllll}
\hline Groups & ALT $(U / L)$ & AST $(U / L)$ & ALP $(U / L)$ & CPK (U/L) \\
\hline Vehicle control & $41.3 \pm 1.65^{\mathrm{e}}$ & $23 \pm 0.26^{\mathrm{g}}$ & $127 \pm 3.28^{\mathrm{b}}$ & $133 \pm 4.04^{\mathrm{g}}$ \\
Positive control & $47.3 \pm 1.87^{\mathrm{b}}$ & $28 \pm 0.63^{\mathrm{d}}$ & $143 \pm 3.57^{\mathrm{b}}$ & $139 \pm 3.28^{\mathrm{ef}}$ \\
Disease control & $93.20 \pm 2.64^{\mathrm{a}}$ & $67.80 \pm 2.05^{\mathrm{a}}$ & $356 \pm 5.69^{\mathrm{a}}$ & $234 \pm 4.97^{\mathrm{a}}$ \\
DSL LD (P) & $45.31 \pm 2.28^{\mathrm{c}}$ & $24.65 \pm 1.01^{\mathrm{f}}$ & $148 \pm 3.26^{\mathrm{b}}$ & $154 \pm 2.32^{\mathrm{c}}$ \\
DSL HD (P) & $42.54 \pm 1.79^{\mathrm{d}}$ & $26.81 \pm 0.86^{\mathrm{e}}$ & $139 \pm 4.02^{\mathrm{b}}$ & $146 \pm 2.86^{\mathrm{d}}$ \\
DIL LD (P) & $42.81 \pm 1.66^{\mathrm{d}}$ & $29.34 \pm 1.28^{\mathrm{c}}$ & $152 \pm 3.89^{\mathrm{b}}$ & $159 \pm 3.47^{\mathrm{b}}$ \\
DIL HD (P) & $40.76 \pm 2.26^{\mathrm{e}}$ & $28.11 \pm 0.94^{\mathrm{d}}$ & $143 \pm 2.93^{\mathrm{b}}$ & $151 \pm 3.63^{\mathrm{c}}$ \\
DSL HD (T) & $39.64 \pm 1.95^{\mathrm{f}}$ & $29.06 \pm 0.68^{\mathrm{c}}$ & $135 \pm 3.61^{\mathrm{b}}$ & $141 \pm 2.79^{\mathrm{e}}$ \\
DIL HD (T) & $38.32 \pm 1.58^{\mathrm{g}}$ & $30.01 \pm 1.14^{\mathrm{b}}$ & $129 \pm 4.01^{\mathrm{b}}$ & $138 \pm 3.34^{\mathrm{f}}$ \\
\hline
\end{tabular}

Results are represented as mean \pm SD $(n=6$, where $n=$ number of rats analysed in each group). Mean values with different superscripts (a-g) in the columns are significantly $(p<0.05)$ different from one another 
Table 7 Biochemical investigation of control and leukemic rats

\begin{tabular}{lllllll}
\hline Groups & Urea $(\mathrm{mg} / \mathrm{dl})$ & Creatinine $(\mathrm{mg} / \mathrm{dl})$ & Bilirubin $(\mathrm{mg} / \mathrm{ml})$ & Albumin $(\mathrm{g} / \mathrm{dl})$ & Globulin $(\mathrm{g} / \mathrm{dl})$ & Total protein $(\mathrm{g} / \mathrm{dl})$ \\
\hline Vehicle control & $29 \pm 1.76^{\mathrm{g}}$ & $1.01 \pm 0.11^{\mathrm{b}}$ & $2.7 \pm 0.17^{\mathrm{e}}$ & $3.9 \pm 0.18^{\mathrm{c}}$ & $2.8 \pm 0.13^{\mathrm{b}}$ & $6.70 \pm 0.32^{\mathrm{c}}$ \\
Positive control & $26 \pm 1.01^{\mathrm{h}}$ & $1.08 \pm 0.14^{\mathrm{b}}$ & $2.67 \pm 0.21^{\mathrm{e}}$ & $4.07 \pm 0.24^{\mathrm{c}}$ & $2.79 \pm 0.16^{\mathrm{b}}$ & $6.86 \pm 0.38^{\mathrm{b}}$ \\
Disease control & $72.2 \pm 2.76^{\mathrm{a}}$ & $2.89 \pm 0.54^{\mathrm{a}}$ & $7.56 \pm 0.97^{\mathrm{a}}$ & $1.20 \pm 0.07^{\mathrm{e}}$ & $0.94 \pm 0.07^{\mathrm{g}}$ & $2.14 \pm 0.11^{\mathrm{f}}$ \\
DSL LD (P) & $36.21 \pm 0.98^{\mathrm{b}}$ & $1.19 \pm 0.09^{\mathrm{b}}$ & $3.21 \pm 0.09^{\mathrm{b}}$ & $4.56 \pm 0.15^{\mathrm{a}}$ & $2.05 \pm 0.09^{\mathrm{f}}$ & $6.61 \pm 0.53^{\mathrm{c}}$ \\
DSL HD (P) & $32.34 \pm 1.76^{\mathrm{e}}$ & $1.06 \pm 0.12^{\mathrm{b}}$ & $2.89 \pm 0.64^{\mathrm{d}}$ & $4.01 \pm 0.21^{\mathrm{c}}$ & $2.98 \pm 0.18^{\mathrm{a}}$ & $6.99 \pm 0.59^{\mathrm{a}}$ \\
DIL LD (P) & $35.14 \pm 0.85^{\mathrm{c}}$ & $1.12 \pm 0.11^{\mathrm{b}}$ & $3.04 \pm 0.33^{\mathrm{c}}$ & $4.32 \pm 0.19^{\mathrm{b}}$ & $2.56 \pm 0.15^{\mathrm{c}}$ & $6.88 \pm 0.63^{\mathrm{ab}}$ \\
DIL HD (P) & $34.12 \pm 1.23^{\mathrm{d}}$ & $1.08 \pm 0.08^{\mathrm{b}}$ & $2.98 \pm 0.26^{\mathrm{c}}$ & $4.27 \pm 0.26^{\mathrm{b}}$ & $2.32 \pm 0.13^{\mathrm{d}}$ & $6.59 \pm 0.49^{\mathrm{c}}$ \\
DSL HD (T) & $30.09 \pm 2.05^{\mathrm{f}}$ & $1.01 \pm 0.10^{\mathrm{b}}$ & $2.48 \pm 0.08^{\mathrm{f}}$ & $3.64 \pm 0.17^{\mathrm{d}}$ & $2.39 \pm 0.08^{\mathrm{d}}$ & $6.03 \pm 0.37^{\mathrm{e}}$ \\
DIL HD (T) & $28.20 \pm 1.87^{\mathrm{g}}$ & $1.02 \pm 0.07^{\mathrm{b}}$ & $2.42 \pm 0.39^{\mathrm{f}}$ & $3.96 \pm 0.23^{\mathrm{c}}$ & $2.19 \pm 0.11^{\mathrm{e}}$ & $6.15 \pm 0.42^{\mathrm{d}}$ \\
\hline
\end{tabular}

Values are represented as mean $\pm S D(n=6$, where $n=$ number of rats analysed in each group). Means with different superscripts (a-h) in the columns are significantly $(p<0.05)$ different from one another

protein. Treatment groups of DSL-EA and DIL-EA have significantly $(p<0.05)$ lowered the level of TBARs i.e. $83.49 \pm$ and $92.25 \pm 1.17 \mathrm{nM} / \mathrm{min} / \mathrm{mg}$ protein respectively. Estimated NO level was markedly high in disease control group with value $93.81 \pm 2.88 \mu \mathrm{M} / \mathrm{ml}$ while positive control group showed significant decrease in $\mathrm{NO}$ level i.e. $61.74 \pm 1.98 \mu \mathrm{M} / \mathrm{ml}$. Low and high doses of DSL-EA and DIL-EA exhibited expressively reduced NO levels compared to disease control group with values not higher than $65 \mu \mathrm{M} / \mathrm{ml}$ in any of the study groups. Results are given in Table 9 .

\section{Histological investigation}

Histological investigations have verified and endorsed the effects of EA extracts of selected Datura species on the studied biochemical parameters (particularly LFTs). Liver and kidney of the vehicle and positive control groups (group I and III) exhibited normal morphological features i.e. intact hepatocytes, sinusoids, typical central veins, Bowman's capsule and glomerular tuft. Benzene treated disease control group caused significant damage to liver and kidney tissues i.e. necrosed hepatocytes, cellular hypertrophy, hylinization of glomerular tuft and marked degeneration of renal tubules as evident in
Figs. 3 and 4 (10X images in Additional files 4-21). Low and high doses of administered extracts alleviated benzene induced damage to a greater extent as evident in the figure (Group IV-IX). These images further reinforce the findings of biochemical and enzymatic parameters.

\section{Percent alleviative effects of Datura extracts in benzene induced leukemia}

The antileukemic effects of DSL-EA and DIL-EA are summarized in Table 10. Percent alleviating effects of both extracts against benzene induced leukemia are collectively illustrated in the table. Apart from the activity levels of antioxidant enzymes i.e. CAT, POD, SOD and GST, where DIL-EA exhibited an expressively greater curative effect, all other parameters were stabilized in a comparative and significant manner by both extracts.

\section{Discussion}

Irregularities in the molecular processes within the cell if not alleviated and mitigated promptly may ultimately result in tumor cell proliferation. Natural remedies are long considered legitimate starting materials for discovery of novel anticancer agents. Since traditional consumption of

Table 8 Effect of Datura extracts on activity levels of endogenous antioxidant enzymes

\begin{tabular}{|c|c|c|c|c|}
\hline Groups & CAT (U/min) & POD (U/min) & SOD (U/mg protein) & GST $(\mathrm{nM} / \mathrm{min} / \mathrm{ml})$ \\
\hline Vehicle control & $1.7 \pm 0.02^{c}$ & $2.1 \pm 0.03^{e}$ & $4.00 \pm 0.05^{a}$ & $216.04 \pm 1.46^{c}$ \\
\hline Positive control & $2.2 \pm 0.04^{b}$ & $3.1 \pm 0.06^{c}$ & $3.51 \pm 0.03^{b}$ & $236.04 \pm 1.46^{\mathrm{b}}$ \\
\hline Disease control & $0.5 \pm 0.04^{e}$ & $1 \pm 0.04^{g}$ & $0.96 \pm 0.05^{9}$ & $81.01 \pm 0.44^{9}$ \\
\hline DSL LD (P) & $0.9 \pm 0.07^{d}$ & $1.7 \pm 0.02^{f}$ & $2.42 \pm 0.02^{f}$ & $108.03 \pm 0.63^{f}$ \\
\hline DSL HD (P) & $1 \pm 0.006^{d}$ & $2.2 \pm 0.01^{\mathrm{e}}$ & $2.83 \pm 0.04^{d}$ & $162.02 \pm 0.70^{d}$ \\
\hline DIL LD (P) & $1.8 \pm 0.06^{c}$ & $1.6 \pm 0.04^{f}$ & $2.79 \pm 0.02^{d}$ & $108.02 \pm 1.03^{f}$ \\
\hline DIL HD (P) & $2.0 \pm 0.13^{b}$ & $4.2 \pm 0.03^{a}$ & $3.18 \pm 0.03^{c}$ & $297.05 \pm 1.60^{a}$ \\
\hline DSL HD (T) & $2.1 \pm 0.08^{b}$ & $2.8 \pm 0.09^{d}$ & $2.65 \pm 0.10^{e}$ & $135.02 \pm 0.63^{\mathrm{e}}$ \\
\hline DIL HD (T) & $2.5 \pm 0.15^{a}$ & $3.9 \pm 0.10^{b}$ & $2.72 \pm 0.09^{e}$ & $162.03 \pm 1.54^{d}$ \\
\hline
\end{tabular}

Results are expressed as mean \pm SD ( $n=6$, where $n=$ number of rats analysed in each group). Values with different superscripts (a-g) in the columns indicate they are significantly $(p<0.05)$ different form each other 
Table 9 TBARs and NO estimation of controls and leukemic rats

\begin{tabular}{lll}
\hline Groups & TBARs $(\mathrm{nM} / \mathrm{min} / \mathrm{mg}$ protein) & $\mathrm{NO}(\mu \mathrm{M} / \mathrm{ml})$ \\
\hline Vehicle control & $88.90 \pm 1.87^{\mathrm{f}}$ & $60.74 \pm 2.23^{\mathrm{e}}$ \\
Positive control & $85.80 \pm 1.09^{\mathrm{g}}$ & $61.74 \pm 1.98^{\mathrm{d}}$ \\
Disease control & $133.75 \pm 2.61^{\mathrm{a}}$ & $93.81 \pm 2.88^{\mathrm{a}}$ \\
DSL LD (P) & $113.77 \pm 2.1^{\mathrm{b}}$ & $60.56 \pm 1.62^{\mathrm{e}}$ \\
DSL HD (P) & $100.82 \pm 1.48^{\mathrm{d}}$ & $62.52 \pm 2.25^{\mathrm{c}}$ \\
DIL LD (P) & $113.12 \pm 2.32^{\mathrm{b}}$ & $62.81 \pm 2.73^{\mathrm{c}}$ \\
DIL HD (P) & $105.82 \pm 1.62^{\mathrm{c}}$ & $64.89 \pm 2.64^{\mathrm{b}}$ \\
DSL HD (T) & $83.49 \pm 1.19^{\mathrm{h}}$ & $62.22 \pm 1.76^{\mathrm{c}}$ \\
DIL HD (T) & $92.25 \pm 1.77^{\mathrm{e}}$ & $63.41 \pm 1.59^{\mathrm{b}}$
\end{tabular}

Results are expressed as mean \pm SD $(n=6$, where $n=$ number of rats analysed in each group). Mean values with different superscripts (a-h) in individual columns specify significance at $p<0.05$

plants as herbs and medicine have been practiced for many centuries, we have chosen two Datura species and designed our study to evaluate their anticancer potential by employing a wide spectrum of in vitro anticancer assays. Moreover, in vivo antileukemic assay of potent extracts was also performed. A schematic plan was followed in execution of current study. Preliminary phytochemical screening and in vitro assessment of the antioxidant potential of 32 (16 for each specie) extracts of root, stem, leaf and flower parts of selected Datura species was the starting point of this study. It was followed by selection of most active extracts based on observed results. After toxicity studies of chosen extracts, they were utilized in predetermined doses for the estimation of in vivo antileukemic activity in rats.

Ethyl acetate leaf extracts of Datura stramonium (DSL-EA) and Datura inoxia (DIL-EA) were the two extracts selected out of 32 owing to their efficacy in preliminary testing. Phytochemical screening of DSL-EA and DIL-EA showed TPC of $28.67 \pm 0.97$ and $27.69 \pm$ $1.12 \mu \mathrm{g} \mathrm{GAE} / \mathrm{mg}$ extract, while TFC of $16.16 \pm 0.06$ and $20.17 \pm 0.17 \mu \mathrm{g}$ QE/mg extract respectively. Polyphenolic compounds i.e. flavonoids, tannins and phenolic acids are the chief contributor to antioxidant properties of majority of medicinal plants. The presence of important functional groups like ketonic, hydroxyl, phenolic and methoxy render these compounds significant antioxidant activity [32, 33]. These compounds are considered as pharmacologically important due to properties like inhibition of lipid peroxidation and free radical scavenging $[19,20]$. HPLC-DAD quantification revealed notable quantities of important polyphenols including rutin, gallic acid, catechin and apigenin in DSL-EA and caffeic acid in DIL-EA. Detection of all these polyphenols further potentiates the medicinal value of selected Datura species. The polyphenols detected and quantified in selected extracts have established pharmacological uses i.e. rutin is known for its anticancer, antidiabetic and antioxidant properties [34], apigenin has known anticancer and anti-inflammatory potential [35] and it is also known to induce autophagy in leukemia cells [19]. Gallic acid has numerous medicinal uses particularly its application as antiangiogenic, anticancer, anti-inflammatory and as an antimicrobial agent [36]. Antioxidant properties of caffeic acid are extensively studied, in one such study it surpassed numerous other antioxidants in curbing aflatoxin generation by more than 95\% [7]. Apart from antioxidant properties, these polyphenols have documented likelihood to impede cancer cell proliferation, activation of pro-carcinogens and inhibit growth signaling pathways and thus prevent cancer cell proliferation $[37,38]$. A study has reported substantial correlation between the occurrence of polyphenols and in vivo tumor growth inhibition via regulating MAPK/ERK, PI3K/AKT and STAT3 pathways in lung metastasis and breast cancer stem cells [39]. The antioxidant potential (TAC and TRP) displayed by DSL-EA $(160.92 \pm 3.00$ and $50.43 \pm$ $1.72 \mu \mathrm{g} \mathrm{AAE} / \mathrm{mg}$ extract respectively) and DIL-EA $(140.44 \pm 5.6$ and $44.02 \pm 1.30 \mu \mathrm{g} \mathrm{AAE} / \mathrm{mg}$ extract respectively) might well be attributed to the presence of these polyphenols along with many others which are not quantified in the present study.

Cytotoxicity testing of extracts using a series of in vitro models including brine shrimps (Artemia salina) larvae, Streptomyces $85 \mathrm{E}$ strain and activity against different cancer cell lines was also performed. Bioactivity profile was established initially by testing the extracts against brine shrimps larvae. Results showed a concentration dependent lethality of DSL-EA and DIL-EA against shrimps. The determination of cytotoxic potential of natural products can be determined reliably with the aid of brine shrimp lethality assay [40]. This assay is typically performed to deduce the safety and quantify the bioactivity of plant extracts using a simple zoological organism. Plant extracts with $\mathrm{LC}_{50}$ values less than $1000 \mu \mathrm{g} / \mathrm{ml}$ against brine shrimps larvae are considered to possess cytotoxic potential [41]. Extremely significant results necessitated further scrutiny using available models to validate the cytotoxicity of extracts to reinforce our findings.

Extracts were also screened for their protein kinase inhibitory potential. Streptomyces $85 \mathrm{E}$ require protein kinases for their aerial hyphae formation which is the basic principle behind the performance of this assay. Kinases play a key role in cell proliferation, division and are considered as critical factors in carcinogenesis [42, 43]. This assay is thus performed for the determination of kinase inhibitory and ultimately anticancer action of extracts. Bald phenotypic zones of $12.5 \mathrm{~mm}$ (MIC: $100 \pm 3.03 \mu \mathrm{g} / \mathrm{disc}$ ) and $19 \mathrm{~mm}$ (MIC: $25 \pm 1.62 \mu \mathrm{g} /$ disc) were displayed by DSL-EA and DIL-EA respectively which confirm substantial protein kinase inhibitory activity. Recently, the 


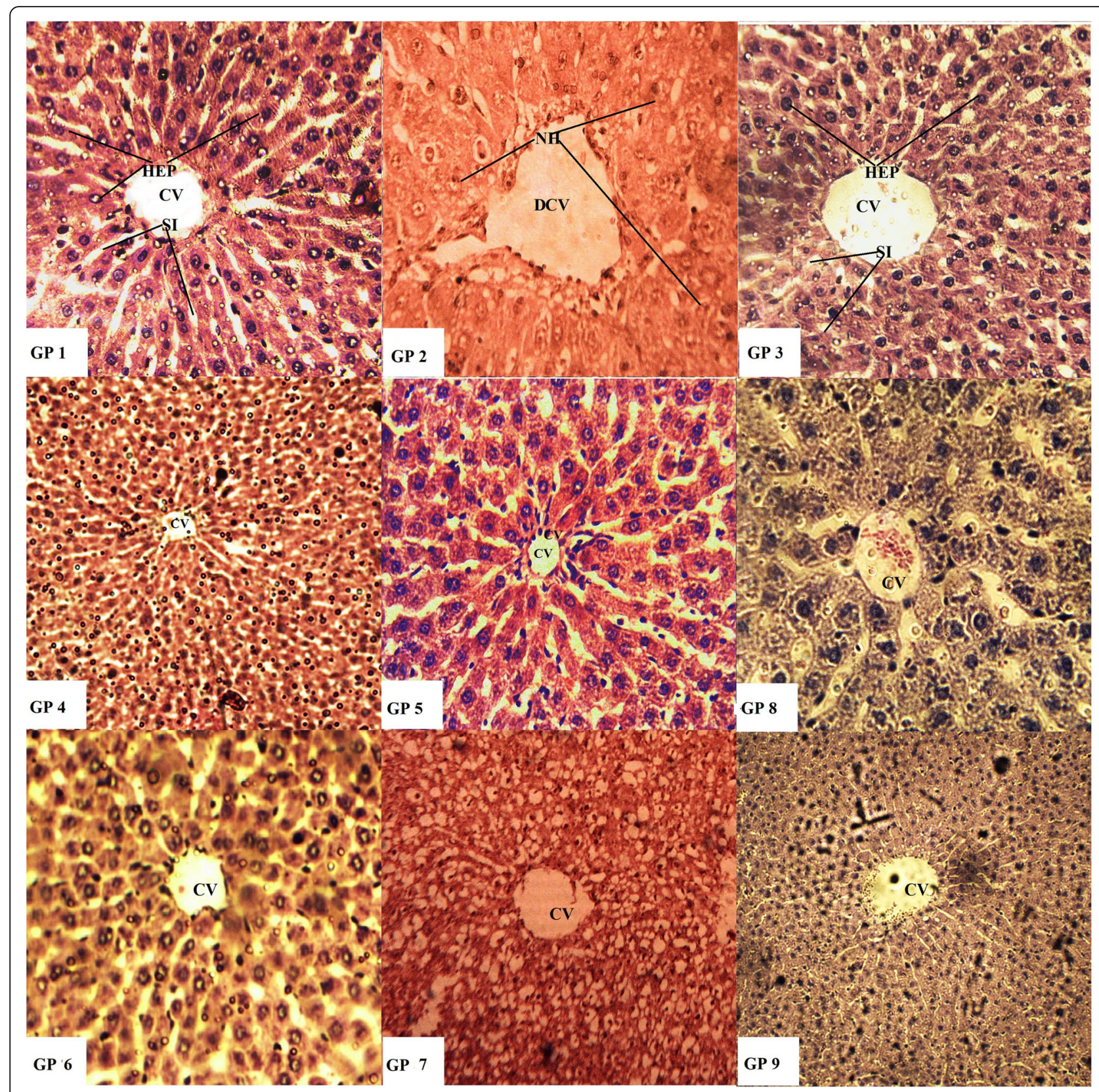

Fig. 3 Hematoxylin-eosin stain. Histopathological observations (40X) for the protective potential of ethyl acetate extracts of D.stramonium and D. inoxia on liver in rat. Gp I: Vehicle control (10\% DMSO in water), Gp II: Disease control (0.2 ml Benzene), Gp III:Positive control (Cyclophosphamide 10 mg/kg), Gp IV: DSL-LD (100 mg/kg, Preventive), Gp V: DSL-HD (200 mg/kg, Preventive), Gp VI: DIL-LD (100 mg/kg, Preventive), Gp VII: DIL-HD (200 mg/kg, Preventive), Gp VIII: DSL-HD (200 mg/kg, Treatment) and Gp IX: DIL-HD (200 mg/kg, Treatment). CV- Central vein, DCV- Damaged central vein, HEP- Hepatocytes, NH- Necrosed hepatocytes

development of protein kinase inhibitors from natural sources particularly from plants has generated renewed interest in targeting kinases. It is because of the fact that protein kinases have a major role to play in cell growth and development, progression of cell cycle and signals transduction across the nuclear membrane [20]. Mutations in genes specifically important for cell growth, differentiation and death result in elevated kinase activity at serine/threonine residues usually found in human cancers [44]. Serine/threonine kinases play a critical role in carcinogenesis [42]. Likewise, a study has shown alteration in a subfamily of serine/threonine kinases in ovarian carcinomas [45]. Tyrosin kinases are involved in regulation of cellular functions of normal cells, additionally they play a key role in oncogenesis [43]. It is for this reason that kinase inhibitors have emerged as auspicious targets for 


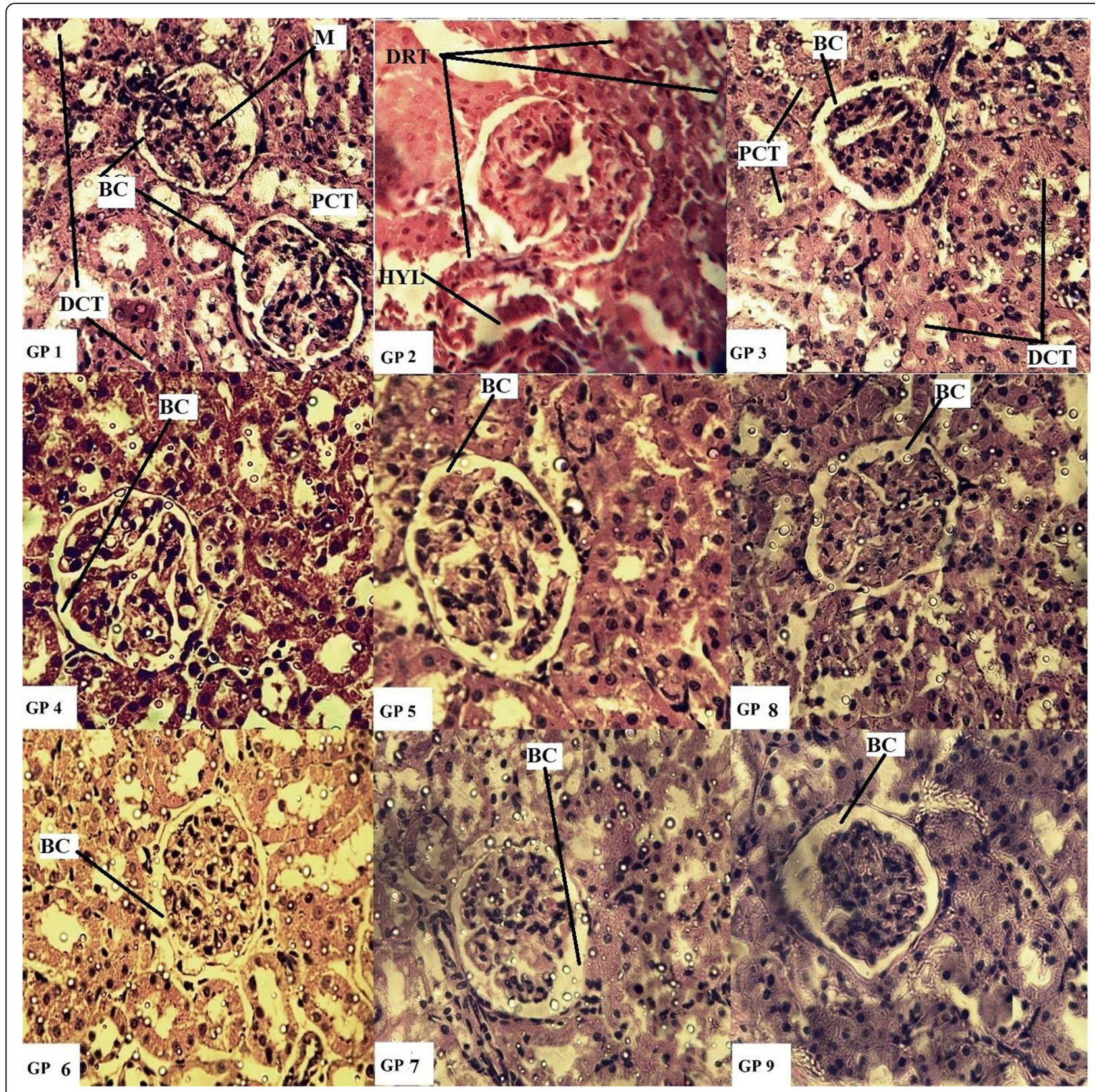

Fig. 4 Hematoxylin-eosin stain. Histopathological observations (40X) for the protective potential of ethyl acetate extracts of D.stramonium and D. inoxia on kidney in rat. Gp I: Vehicle control (10\% DMSO in water), Gp II: Disease control (0.2 ml Benzene), Gp III:Positive control (Cyclophosphamide 10 mg/kg), Gp IV: DSL-LD (100 mg/kg, Preventive), Gp V: DSL-HD (200 mg/kg, Preventive), Gp VI: DIL-LD (100 mg/kg, Preventive), Gp VII: DIL-HD (200 mg/kg, Preventive), Gp VIII: DSL-HD (200 mg/kg, Treatment) and Gp IX: DIL-HD (200 mg/kg, Treatment). BCBowman's capsule, DCT: Distal convoluted tubules, DRT- Degenerated renal tubules, HYL- Hylinization (of glomerular tuft), M- Mesangium, PCTProximal convoluted tubules

cancer treatment [46]. A definite advantage of using whole cell Streptomyces is that the cytotoxic activity of samples can be readily identified using this assay. Furthermore, inhibitors of signal transduction for numerous applications i.e. antitumor, anti-infective and anti-mycobacteria can also be identified with the aid of this simple assay [47].
Anticancer potential of Datura extracts was further assessed against selected cancer cell lines. PC-3 is a human prostate cancer cell line and is used in exploration of numerous biochemical variations in prostate cancer cells and assessment of their response to different anticancer agents. Prostate cancer is one of the most widespread cancers diagnosed in men and developing new 


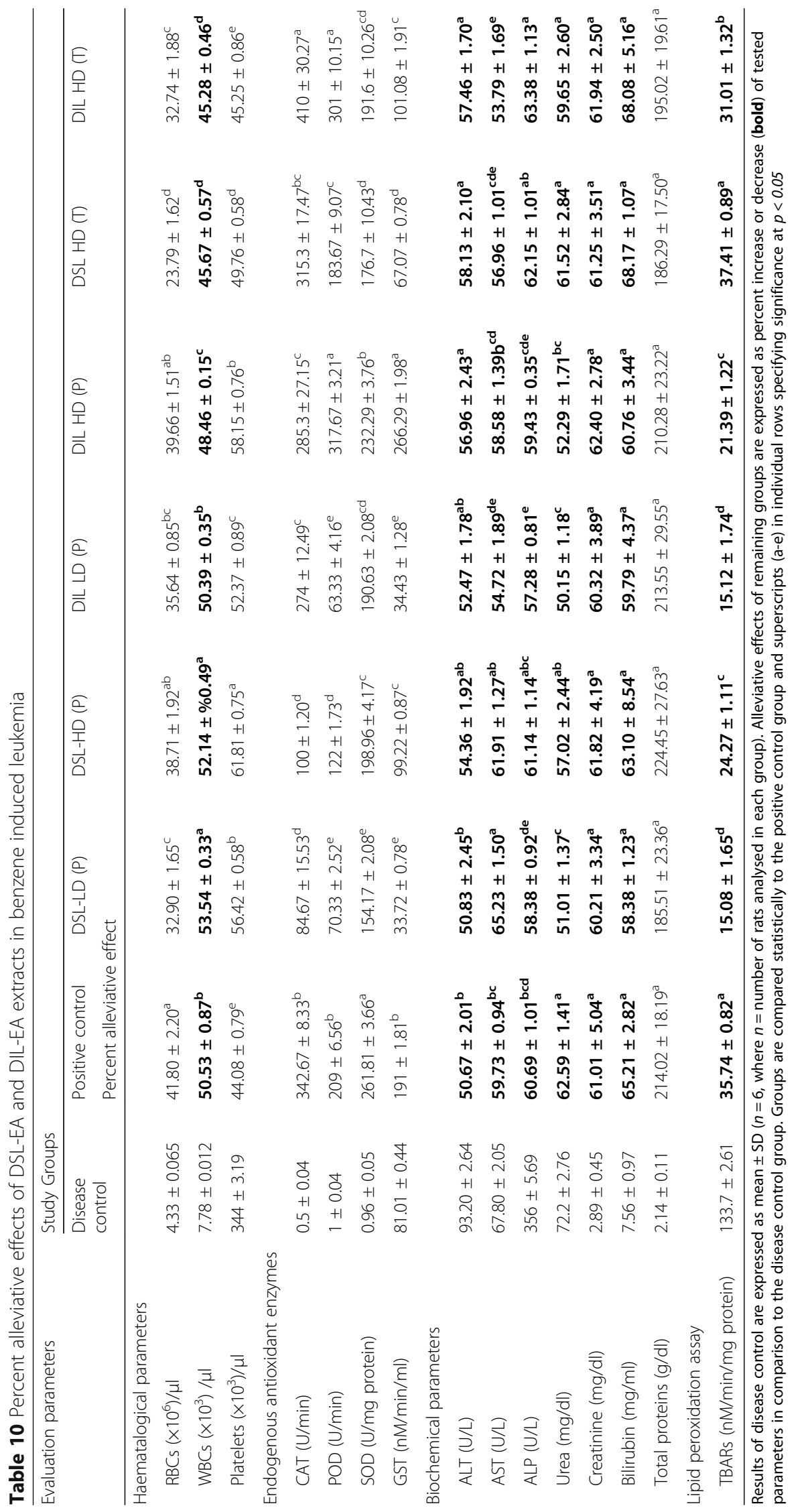


chemotherapeutic agents for its treatment has been quite a challenge [48]. Human breast cancer cell lines MDAMB 231 and MCF-7 were also used in the current study. Breast cancer is a major health problem in women, one in ten of all reported cancers annually is a cancer of female breast [9]. Out of the two Datura species studied, DIL-EA exhibited remarkable activity against each of the three tested cancer cell lines with $\mathrm{IC}_{50}$ values lower than $3.00 \mu \mathrm{g} / \mathrm{ml}$ in each case. DSL-EA on the contrary displayed comparatively weak cytotoxic activity against the chosen cancer cell lines. The anticancer potential of aerial parts and seeds of Datura species against cancer cell lines has been explored previously by numerous researchers using different solvent extracts. DS methanol extract of seeds when tested against MCF-7 cell line displayed an $\mathrm{IC}_{50}$ value of $113.05 \mu \mathrm{g} / \mathrm{ml}$ and the observed activity was postulated to be due to the detected antioxidant potential of the same extract [18]. In another study DS water extract of leaf part was tested at a concentration of $1 \mathrm{mg} / \mathrm{ml}$ against numerous cell lines including MDA-MB 231 and $24 \mathrm{~h}$ exposure led to a significant decline in cell survival rate [49]. DI methanloic leaf extract and one of its constituents from the extract named 'Dinoxin B' were tested for anti-proliferative action against a range of normal and human cancer cell lines. Sub-micromolar $\mathrm{IC}_{50}$ values were observed against different cancer cells and the most sensitive ones were various breast cancer cell lines. The activity was accredited to the presence of Dinoxin B found specifically in leaf portion of D.inoxia [14]. Dinoxin B is fom the withanolide class of natural products. Keeping many of the previously reported studies in sight, we can infer that antioxidant moieties as well as different withanolides reported in Datura species might well be responsible for the remarkable anticancer activity of DIL-EA as well as the modest activity profile of DSL-EA.

Lymphocyte toxicity assessment revealed no significant cytotoxic action of either DSL-EA or DIL-EA against normal human lymphocytes. Acquired results affirmed the selective nature of cytotoxic action of Datura extracts against cancer cells. Results of acute toxicity study further supported the plan to perform in vivo antileukemic assay as both species of Datura at doses up to $2 \mathrm{~g} /$ $\mathrm{kg}$ were found to have no damaging and deleterious effects on rats used in the study.

Leukemia is amongst the most prominent cancer forms both in infants and adults and is characterized by unrestrained formation, multiplication and accumulation of malignant white blood cells in bone marrow and peripheral blood [50]. The exact cause of leukemia is fundamentally unknown but occupational and environmental factors are considered as significant contributors to the onset and progression of the disease. Mutations in DNA as a result of oncogenes activation or deactivation of tumor suppression genes is considered the main causative factor of leukemia. Apart from sporadic mutations, few occur as a result of certain predisposing factors like exposure to different carcinogens [51]. One such carcinogen is benzene which is associated with many health hazards. The induction of hematological toxicity by benzene has been reported over a century ago and fresh studies have also linked benzene to haematotoxicity even at concentrations less than $1 \mathrm{ppm}$ in air [52, 53]. Benzene cause acute myeloid leukemia (AML) and myelodysplastic syndrome and is also a plausible cause of other hematological disorders including non-Hodgkin lymphoma [54, 55]. The postulated mode of action of benzene (Fig. 5) briefly consists of five major steps: (a) benzene metabolism to its metabolite, benzene oxide; (b) its interaction with target cells in the bone marrow; (c) initiation of mutations in bone marrow cells; (d) designated clonal proliferation of these mutated cells and (e) abnormal growth and multiplication of target cells in bone marrow resulting in neoplasia (leukemia) [56].

The antileukemic potential of DSL-EA and DIL-EA on male Sprague Dawley rats bearing benzene induced leukemia was assessed on the basis of results acquired from a series of haematological, biochemical, enzymatic and histological studies. Significantly decreased RBCs, platelets and haemoglobin levels while elevated WBCs and ESR in disease control rats established the fact that leukemia was induced in this group. Marked elevation in WBCs count is one of the prominent signs of acute leukemic condition. Results revealed a $40-50 \%$ decrease in WBCs count in study groups when compared to negative control. Leukemia induction in rats by benzene administration is previously reported in numerous studies $[11,26,27,59]$. Comparison of study groups clearly revealed the protective effect of low and high doses of Datura extracts. There was no statistically significant difference $(p<0.05)$ between the calculated haematological parameters of treatment and preventive groups when compared with the positive control group. It showed that administered doses of extracts have shown fairly comparable antileukemic activity to the standard drug used in current study. Polyphenols detected in phytochemical investigation might be responsible for potentiating the vasoprotective and vasotonic effects of DSL-EA and DIL-EA.

Exposure to benzene has been reported to cause liver damage since it is the major organ responsible for compound metabolism into inert and potentially toxic metabolites. Enzymatic conversion of benzene to reactive species can lead to oxidative stress. These species can interact with tissues and cell membranes causing lipid peroxidation which can further aggravate liver injury [60-62]. Abnormalities in level of serum enzymes and macromolecules signifying liver functionality, including 


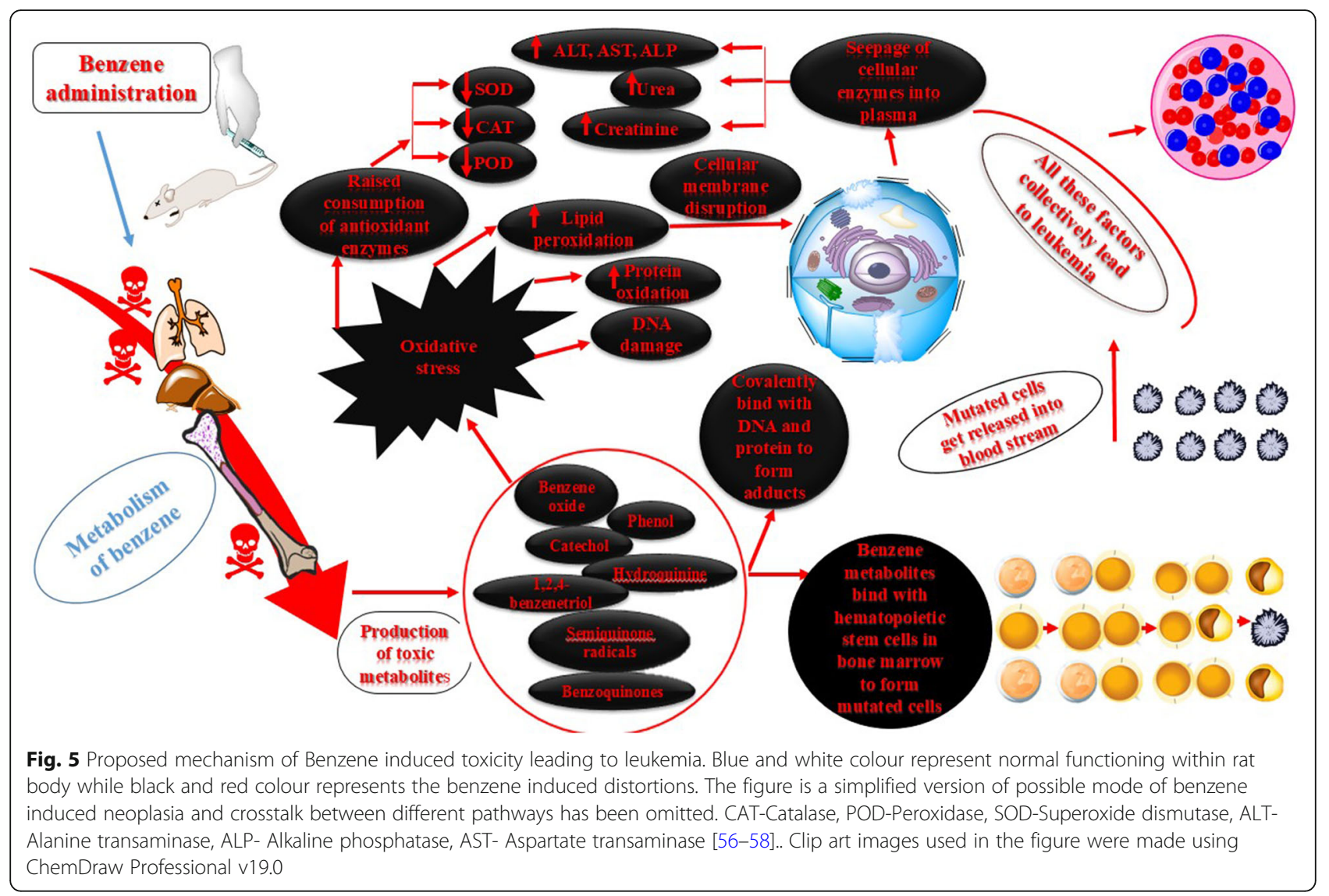

ALT, AST and ALP as well as bilirubin and total proteins clearly indicated liver injury in disease control rats. The incidence of liver injury is very common in hematological diseases particularly leukemia [63]. Preventive and treatment groups of both extracts reverted liver damage to a great extent as evident by their statistically significant $(\mathrm{p}<0.05)$ difference from disease control group. Although the biochemical mechanism for regeneration of liver enzymes and functionality is not clear, nevertheless inhibition of lipid peroxidation and free radical scavenging properties of polyphenolic compounds might be responsible for curbing the damage caused to liver by benzene $[19,20]$.

Kidney acts as one of the major organs responsible for detoxification and waste elimination rendering it highly susceptible to toxins induced injury. Benzene induced nephrotoxicity has been documented previously [62] Glomerulonephritis and nephrotic syndrome without evident kidney failure have been reported in leukemia and lymphoma. Tumor lysis and cell bursting in acute leukemic conditions result in elevated potassium, phosphate and decreased calcium level along with acid-base imbalance. All these anomalies result in kidney failure characterized initially by significantly elevated serum urea and creatinine level [64]. Benzene administration posed significant nephrotoxic effects. Disease control rats were the most affected ones based on highest estimated values of selected nephrotoxicity markers. Datura species at low and high doses lowered urea and creatinine levels in a manner comparable to the positive control. Nephroprotective effect observed in the current study further strengthened the potential antileukemic action of used extracts.

The role played by oxidants in different stages of carcinogenesis is well documented [65]. Cells using aerobic metabolism for their energy needs, inevitably generate ROS [66]. Extensive accumulation of ROS mediate harm to biomolecules and causes deleterious effects resulting in numerous diseases including haematopoietic malignancies [67]. There is a well-documented association between oxidative stress and leukemia, higher amounts of ROS are generated by leukemic cells as compared to normal cells because they are under a recurrent state of oxidative blockade [68]. The damaging effects mediated by ROS can be nullified by action of enzymatic and nonenzymatic antioxidants. Endogenous antioxidant enzymes including CAT, POD, SOD and GST play a significant role in combating oxidative stress [67]. Conversion of $\mathrm{H}_{2} \mathrm{O}_{2}$ to $\mathrm{H}_{2} \mathrm{O}$ and $\mathrm{O}_{2}$ via catalytic conversion is triggered by $\mathrm{CAT}$, which is a major antioxidant enzyme present in 
aerobic cells. SOD, on the other hand dismutates superoxide anion radical $\left(2 \mathrm{O}_{2}\right)$ to less toxic $\mathrm{H}_{2} \mathrm{O}_{2}$ and molecular oxygen $/ \mathrm{O}_{2}$ by redox mechanism. A selenoprotein prevalent in cytosol and mitochondrial matrix, POD, is involved in the catalytic reduction of lipid peroxides and $\mathrm{H}_{2} \mathrm{O}_{2}$ [30]. GSTs are evolutionarily conserved enzymes that play a key role in detoxification of numerous xenobiotics. The conjugation of reduced glutathione (GSH) to electrophilic substrates is catalyzed by GSTs resulting in production of easily soluble and less toxic compounds [69]. Level of these endogenous enzymes is disturbed due to oxidative overload. There are contradictory reports in the literature regarding the level of endogenous antioxidant enzymes in various types of cancers [58]. In our study, benzene treated disease control group showed severely reduced activity levels of CAT, POD, SOD and GST. These findings reinforce the observed aberrations perpetrated by the leukemogenic chemical used in current study. Excessive ROS generation and extended oxidative stress following benzene doses and leukemia induction might have led to exhaustion of endogenous antioxidant defense system particularly the antioxidant enzymes. Furthermore, the expression of endogenous antioxidant enzymes might also be adversely affected. Administration of EA leaf extracts of both plants ameliorated the oxidative stress in a dose dependent manner. Low doses yielded mild restorative effects while greater results were observed in case of high doses of both preventive and treatment modes. The restorative effect might well be accredited to the presence of useful polyphenols and other antioxidant moieties within Datura species.

Weakened antioxidant defense system result in increased lipid peroxidation with consequent deterioration in cellular membrane integrity and cellular functions. There are numerous end products of lipid peroxidation including TBARs. These are considered as effective markers of oxidative disorders and numerous cancers including leukemia [27, 70]. As revealed by the estimated biochemical parameters, the antioxidant defense system of disease control rats was highly affected. Inflated oxidative degradation of lipids was thus an anticipated outcome. Both extracts expressively lowered TBARs level in treatment mode, while high doses in preventive mode also resulted in mild recovery. Escalated NO level in disease control rats further press the possibility of an irreversible damage to lipoproteins and cellular membrane owing to the tendency of NO to react with $\cdot \mathrm{O}_{2}$ and generation of highly volatile peroxynitrite. These aberrations were also curbed by high and low doses of extracts in identical manner.

Detection of medicinally important phytochemicals, endowed with antioxidant activity in current study and the documented evidence of occurrence of compounds i.e. withanloides [71] may be responsible for the observed anticancer action of Datura extracts. Withanolides have proven cytotoxic action in numerous cancer cell types including leukemia. These compounds act through diverse molecular mechanisms i.e. induction of apoptosis via down regulation of akt phosphorylation [72], or through activation of p38 mitogen activated protein kinase (MAPK) signaling cascade resulting in elevated levels of BAX (Bcl-2- associated X protein) and ultimately, initiation of mitochondrial cell death [73]. Findings of our study further deduce the alleviating effects of selected species of Datura in benzene induced leukemia. Despite the fact that animal models have numerous common properties with human physiology, due diligence must be performed when trying to extrapolate findings from an animal model of a disease to a clinical trial setting.

\section{Conclusion}

In view of the results obtained in phytochemical and biological evaluation of different extracts of D. stramonium and $D$. inoxia, a comprehensive study targeting the anticancer prospects of selected extracts seemed highly prudent. The presence of important secondary metabolites including phenolics and flavonoids with substantial antioxidant properties further support the undertaken study. Significant in vitro anticancer activity in addition to relatively selective action against cancerous cells deemed these extracts as suitable candidates for subsequent in vivo evaluation. Antileukemic action as appraised by haematological, biochemical and histological evaluation as well as endogenous antioxidant enzymes levels clearly indicate the significant ameliorating effects of selected extracts against benzene induced leukemia. Both species yielded comparable brine shrimp lethality, protein kinase inhibitory and in vivo antileukemic results while D.inoxia showed significantly greater in vitro anticancer potential against prostate and breast cancer cell lines. The findings from the current study fully support the need for detailed molecular investigation to determine the mechanism(s) responsible for the observed anticancer actions.

\section{Supplementary information}

Supplementary information accompanies this paper at https://doi.org/10. 1186/s12906-020-02975-8.

Additional file 1. Fig Ad2a. Chromatogram of standard polyphenols, Additional file 2. Fig Ad2b. Chromatogram of compounds detected in DSLEA

Additional file 3 Fig Ad2c. Chromatogram of compounds detected in DILEA.

Additional file 4. Fig Ad3a. Histopathological observations (10X) of Gp I liver.

Additional file 5. Fig Ad3b. Histopathological observations (10X) of Gp 2 liver. 
Additional file 6. Fig Ad3c. Histopathological observations (10X) of Gp 3 liver.

Additional file 7. Fig Ad3d. Histopathological observations (10X) of Gp 4 liver.

Additional file 8. Fig Ad3e. Histopathological observations (10X) of Gp 5 liver.

Additional file 9. Fig Ad3f. Histopathological observations (10X) of Gp 6 liver.

Additional file 10. Fig Ad3g. Histopathological observations (10X) of Gp 7 liver.

Additional file 11. Fig Ad3h. Histopathological observations (10X) of Gp 8 liver.

Additional file 12. Fig Ad3i. Histopathological observations (10X) of Gp 9 liver.

Additional file 13. Fig Ad4a. Histopathological observations (10X) of Gp 1 Kidney.

Additional file 14. Fig Ad4b. Histopathological observations (10X) of Gp 2 Kidney.

Additional file 15. Fig Ad4c. Histopathological observations (10X) of Gp 3 Kidney.

Additional file 16. Fig Ad4d. Histopathological observations (10X) of Gp 4 Kidney.

Additional file 17. Fig Ad4e. Histopathological observations (10X) of Gp 5 Kidney.

Additional file 18. Fig Ad4f. Histopathological observations (10X) of Gp 6 Kidney.

Additional file 19. Fig Ad4g. Histopathological observations (10X) of Gp 7 Kidney.

Additional file 20. Fig Ad4h. Histopathological observations (10X) of Gp 8 Kidney.

Additional file 21. Fig Ad4i. Histopathological observations (10X) of Gp 9 Kidney.

\section{Abbreviations}

BAX: BCI-2- associated X protein; DCV: Damaged central vein; DIL-EA: Datura inoxia leaf extract in ethyl acetate; DSL-EA: Datura stramonium leaf extract in ethyl acetate; RP-HPLC: Reverse phase high performance liquid chromatography; ALT: Alanine transaminase; ALP: Alkaline phosphatase; AST: Aspartate transaminase; DMSO: Dimethyl sulfoxide; AAE: Ascorbic acid equivalent; GAE: Gallic acid equivalent; QE: Quercetin equivalent; TSB: Trypron soya broth; PBS: Phosphate buffer saline; HIFBS: Heat inactivated foetal bovine serum; MIC: Minimum inhibitory concentration; OECD: Organization for Economic Cooperation and Development; CPK: Creatinine phosphokinase; GST: Glutathione S-transferase; SOD: Superoxide dismutase; CAT: Catalase; MAPK: Mitogen activated protein kinase: POD: Peroxidase.: TBARS: Thiobarbituric acid reactive substances: ESR: Erythrocyte sedimentation rate.; TPC: Total phenolics content.; TFC: Total flavonoids content: TAC: Total antioxidant capacity:i TRP: Total reduction potential.; DPPH: 2-2-diphenyl 1-picrylhydrazyl

\section{Acknowledgments}

Authors would like to acknowledge Prof. Dr. Rizwana Aleem Qureshi, Department of Plant sciences, Faculty of Biological sciences, Quaid-i-Azam University, Islamabad, Pakistan for identifying the plant sample and Dr. Muhammad Rashid Khan for facilitating the in vivo study. We are grateful to Prof. Dr. Bushra Mirza, Department of Biochemistry, Faculty of Biological sciences, Quaid-i-Azam University, Islamabad, Pakistan for her support in carrying out HPLC analysis of selected crude extracts. We also thank Prof. Dr. John J Walsh, School of Pharmacy and Pharmaceutical Sciences, Trinity College Dublin, Ireland for critical review of the manuscript and necessary language corrections.

\section{Authors' contributions}

IH conceptualized and designed the study, supervised execution of experiments, critically revised the manuscript and approved the final version of this manuscript. BN performed experiments, analyzed and interpreted the data, wrote and revised the manuscript. MWB contributed in the conduction of experiments, acquisition of the data and critical review of the manuscript. MM contributed in study design, experimentation and acquisition of the data. SMA assisted in data analysis and interpretation, and made critical revisions. MZIK contributed in the experiments and critically reviewed the figures. STBK substantially contributed in conducting the experiments and revisions in the manuscript. All authors have read and approved the final manuscript.

\section{Funding}

The project was funded by Quaid-i-Azam University, Islamabad, Pakistan through university research fund "QAU-Bio/Pharm.URF-2016". The study was independently designed, conducted and written by the authors. The funding body had no role in collection, analysis and interpretation of the data.

\section{Availability of data and materials}

The datasets used and/or analyzed during the current study are available from the corresponding author on reasonable request.

\section{Ethics approval and consent to participate}

We confirm that any aspect of the work covered in this manuscript that has involved either experimental animals or human patients has been conducted by strictly following the guidelines as approved by the ethical committee of Quaid-i-Azam University, Islamabad, Pakistan (Letter No. QAUPHM-017/2016 for the animal care and Letter No. QAU-PHM-023/2016 for experimentation: Dated 24/10/2016) for this study while blood sampling from healthy volunteer was also approved by Institutional Review board of Quaid-i-Azam University (Letter No. IRB-QAU-116; Dated 4/11/2016). A written informed consent was obtained from the participant in this regard.

\section{Consent for publication}

Not applicable.

\section{Competing interests}

The authors declare that they have no competing interests.

\section{Author details}

${ }^{1}$ Department of Pharmacy, Faculty of Biological Sciences, Quaid-i-Azam University, Islamabad 45320, Pakistan. ${ }^{2}$ Department of Pharmacy, Capital University of Science and Technology, Islamabad 44000, Pakistan.

Received: 29 August 2019 Accepted: 31 May 2020

Published online: 17 June 2020

\section{References}

1. Abdulla M, Gruber P. Role of diet modification in cancer prevention. BioFactors. 2000;12(1-4):45-51.

2. Mao X, Boyd LK, Yáñez-Muñoz RJ, Chaplin T, Xue L, Lin D, Shan L, Berney DM, Young BD, Lu Y-J. Chromosome rearrangement associated inactivation of tumour suppressor genes in prostate cancer. Am J Cancer Res. 2011;1(5):604.

3. Reddy L, Odhav B, Bhoola K. Natural products for cancer prevention: a global perspective. Pharmacol Ther. 2003;99(1):1-13.

4. Vincent TL, Gatenby RA. An evolutionary model for initiation, promotion, and progression in carcinogenesis. Int J Oncol. 2008;32(4):729-37.

5. Klaunig JE, Wang Z, Pu X, Zhou S. Oxidative stress and oxidative damage in chemical carcinogenesis. Toxicol Appl Pharmacol. 2011;254(2):86-99.

6. Bussemakers MJ, van Bokhoven A, Verhaegh GW, Smit FP, Karthaus HF, Schalken JA, Debruyne FM, Ru N, Isaacs WB. DD3:: A new prostate-specific gene, highly overexpressed in prostate cancer. Cancer Res. 1999;59(23): 5975-9.

7. Dai J, Mumper RJ. Plant phenolics: extraction, analysis and their antioxidant and anticancer properties. Molecules. 2010;15(10):7313-52.

8. Bray F, McCarron P, Parkin DM. The changing global patterns of female breast cancer incidence and mortality. Breast Cancer Res. 2004;6(6):229.

9. Ferlay J, Héry C, Autier P, Sankaranarayanan R: Global burden of breast cancer. In: Breast cancer epidemiology. edn.: Springer; 2010: 1-19.

10. Tanner SM, Austin JL, Leone G, Rush LJ, Plass C, Heinonen K, Mrózek K, Sill $H$, Knuutila S, Kolitz JE. BAALC, the human member of a novel mammalian neuroectoderm gene lineage, is implicated in hematopoiesis and acute leukemia. Proc Natl Acad Sci U S A. 2001;98(24):13901-6. 
11. Olufemi AE, Terry AO, Kola OJ. Anti-leukemic and immunomodulatory effects of fungal metabolites of Pleurotus pulmonarius and Pleurotus ostreatus on benzene-induced leukemia in Wister rats. Korean J Hematol. 2012;47(1):67-73.

12. Nobili S, Lippi D, Witort E, Donnini M, Bausi L, Mini E, Capaccioli S. Natural compounds for cancer treatment and prevention. Pharmacol Res. 2009; 59(6):365-78.

13. Bonde K. The genus Datura: from research subject to powerful hallucinogen. Ethnobotanical Leaflets. 2001;1998(1):10.

14. Vermillion $\mathrm{K}$, Holguin FO, Berhow MA, Richins RD, Redhouse T, O'Connell MA, Posakony J, Mahajan SS, Kelly SM, Simon JA. Dinoxin b, a withanolide from datura inoxia leaves with specific cytotoxic activities. J Nat Prod. 2011; 74(2):267-71.

15. Fang S-T, Liu X, Kong N-N, Liu S-J, Xia C-H. Two new withanolides from the halophyte Datura stramonium L. Nat Prod Res. 2013;27(21):1965-70.

16. Ramadan MF, Zayed R, El-Shamy H. Screening of bioactive lipids and radical scavenging potential of some solanaceae plants. Food Chem. 2007;103(3): 885-90.

17. Maheshwari NO, Khan A, Chopade BA. Rediscovering the medicinal properties of Datura sp.: a review. J Med Plants Res. 2013;7(39):2885-97.

18. Iabal S, Sivaraj C, Gunasekaran K. Antioxidant and Anticancer Activities of Methanol Extract of Seeds of Datura stramonium I. Free Radicals \& Antioxidants. 2017; 7(2).

19. Fatima H, Khan K, Zia M, Ur-Rehman T, Mirza B, Haq I-u. Extraction optimization of medicinally important metabolites from Datura innoxia Mill.: an in vitro biological and phytochemical investigation. BMC Complement Alter Med. 2015;15(1):376.

20. Nasir B, Ahmad M, Zahra SS, Fatima H, Ur-Rehman T. Pharmacological evaluation of Fumaria indica (hausskn.) Pugsley; a traditionally important medicinal plant. Pak J Bot. 2017:49:119-32.

21. Ul-Haq I, Ullah N, Bibi G, Kanwal S, Ahmad MS, Mirza B. Antioxidant and cytotoxic activities and phytochemical analysis of Euphorbia wallichii root extract and its fractions. Iran J Pharmaceutic Res. 2012;11(1):241.

22. Zahra SS, Ahmed M, Qasim M, Gul B, Zia M, Mirza B, Haq I-u. Polarity based characterization of biologically active extracts of Ajuga bracteosa Wall. ex Benth. and RP-HPLC analysis. BMC Complement Altern Med. 2017;17(1):443.

23. Ahmed M, Fatima H, Qasim M, Gul B. Polarity directed optimization of phytochemical and in vitro biological potential of an indigenous folklore: Quercus dilatata Lindl. ex Royle. BMC Complement Altern Med. 2017;17(1):386.

24. Khan K, Fatima H, Taqi MM, Zia M, Mirza B. Phytochemical and in vitro biological evaluation of Artemisia scoparia Waldst. \& kit for enhanced extraction of commercially significant bioactive compounds. J Appl Res Med Aromat Plants. 2015;2(3):77-86.

25. Waseem D, Butt AF, Haq I-U, Bhatti MH, Khan GM. Carboxylate derivatives of tributyltin (IV) complexes as anticancer and antileishmanial agents. DARU J. Pharm. Sci. 2017;25(1):8.

26. Akanni EO, Faremi A, Akanni RA, Bamisaye EO, Adewumi FA, Agboola OA, Liasu OI. African polyherbal formulation possesses chemopreventive and chemotherapeutic effects on benzene-induced leukemia in wistar rats. Annu Res Rev Biol. 2017;6(2):1-11.

27. Akanni E, Adedeji A, Adedosu O, Olaniran O, Oloke J. Chemopreventive and anti-leukemic effects of ethanol extracts of Moringa oleifera leaves on wistar rats bearing benzene induced leukemia. Curr Pharm Biotechnol. 2014;15(6): 563-8.

28. Attia AM, Ibrahim FA, Abd El-Latif NA, Aziz SW, Elwan AM, Aziz A, Aziz A, Elgendy A, Elgengehy FT. Therapeutic antioxidant and anti-inflammatory effects of laser acupuncture on patients with rheumatoid arthritis. Lasers Surg Med. 2016;48(5):490-7.

29. Shah NA, Khan MR, Ahmad B, Noureen F, Rashid U, Khan RA. Investigation on flavonoid composition and anti free radical potential of Sida cordata. BMC Complement Altern Med. 2013;13(1):276

30. Batool R, Khan MR, Majid M. Euphorbia dracunculoides L. abrogates carbon tetrachloride induced liver and DNA damage in rats. BMC Complement Altern Med. 2017;17(1):223.

31. Grisham MB, Johnson GG, Lancaster Jr JR: Quantitation of nitrate and nitrite in extracellular fluids. In: Methods Enzymol. Volume 268, edn.: Elsevier; 1996: 237-246.

32. Afshar FH, Delazar A, Nazemiyeh H, Esnaashari S, Moghadam SB. Comparison of the total phenol, flavonoid contents and antioxidant activity of methanolic extracts of Artemisia spicigera and A. splendens growing in Iran. Pharm Sci. 2012;18(3):165-70.
33. Rice-Evans CA, Miller NJ, Paganga G. Structure-antioxidant activity relationships of flavonoids and phenolic acids. Free Radic Biol Med. 1996; 20(7):933-56.

34. Chua LS. A review on plant-based rutin extraction methods and its pharmacological activities. J Ethnopharmacol. 2013;150(3):805-17.

35. Singh JPV, Selvendiran K, Banu SM, Padmavathi R, Sakthisekaran D. Protective role of Apigenin on the status of lipid peroxidation and antioxidant defense against hepatocarcinogenesis in Wistar albino rats. Phytomedicine. 2004;11(4):309-14.

36. Choubey S, Varughese LR, Kumar V, Beniwal V. Medicinal importance of gallic acid and its ester derivatives: a patent review. Pharm Pat Anal. 2015; 4(4):305-15.

37. Hussain SA, Sulaiman AA, Balch C, Chauhan H, Alhadidi QM, Tiwari AK. Natural polyphenols in cancer chemoresistance. Nutr Cancer. 2016;68(6): 879-91.

38. Amin AR, Karpowicz PA, Carey TE, Arbiser J, Nahta R, Chen ZG, Dong J-T, Kucuk O, Khan GN, Huang GS: Evasion of anti-growth signaling: a key step in tumorigenesis and potential target for treatment and prophylaxis by natural compounds. In: Semin Cancer Biol: 2015: Elsevier; 2015: S55-S77.

39. Vuong T, Mallet J-F, Ouzounova M, Rahbar S, Hernandez-Vargas H, Herceg Z, Matar C. Role of a polyphenol-enriched preparation on chemoprevention of mammary carcinoma through cancer stem cells and inflammatory pathways modulation. J Transl Med. 2016;14(1):13.

40. Gelani CD, Uy MM. Cytotoxicity to Artemia salina L. of marine sponge extracts from Surigao del Norte, Phillipines. Bull Env Pharmacol Life Sci. 2016;55:14-8.

41. Nguta JM, Mbaria JM, Gakuya DW, Gathumbi PK, Kabasa JD, Kiama SD: Evaluation of acute toxicity of crude plant extracts from kenyan biodiversity using brine shrimp, Artemia salina I.(artemiidae). In: Open Conf Proc J: 2012; 2012.

42. Kandel ES, Hay N. The regulation and activities of the multifunctional serine/ threonine kinase Akt/PKB. Exp Cell Res. 1999;253(1):210-29.

43. Gschwind A, Fischer OM, Ullrich A. The discovery of receptor tyrosine kinases: targets for cancer therapy. Nat Rev Cancer. 2004;4(5):361.

44. Davies H, Bignell GR, Cox C, Stephens P, Edkins S, Clegg S, Teague J, Woffendin H, Garnett MJ, Bottomley W. Mutations of the BRAF gene in human cancer. Nature. 2002;417(6892):949.

45. Cheng JQ, Godwin AK, Bellacosa A, Taguchi T, Franke TF, Hamilton TC, Tsichlis PN, Testa JR. AKT2, a putative oncogene encoding a member of a subfamily of protein-serine/threonine kinases, is amplified in human ovarian carcinomas. Proc Natl Acad Sci. 1992;89(19):9267-71.

46. Yao G, Sebisubi FM, Voo LYC, Ho CC, Tan GT, Chang LC. Citrinin derivatives from the soil filamentous fungus Penicillium sp. H9318. J. Braz. Chem Soc. 2011:22(6):1125-9.

47. Waters B, Saxena G, Wanggui Y, Kau D, Wrigley S, Stokes R, Davies J. Identifying protein kinase inhibitors using an assay based on inhibition of aerial hyphae formation in Streptomyces. J Antibiot. 2002;55(4):407-16.

48. Nasir B, Humaira F, Ahmed M, Phull A-R. Cannabis: a prehistoric remedy for the deficits of existing and emerging anticancer therapies. J Explor Res Pharmacol. 2017;2(3):93-104.

49. Ahmad IM, Abdalla MY, Mustafa NH, Qnais EY, Abdulla F. Datura aqueous leaf extract enhances cytotoxicity via metabolic oxidative stress on different human cancer cells. JJ of Bio Sci. 2009;2(1):9-14.

50. Gopinath S, Shewade DG, Dubashi B, Kadambari D, Ramesh A, Kesavan R. Effect of p53 codon 72 polymorphism on clinical outcome in locally advanced breast cancer patients receiving anthracycline based neoadjuvant chemotherapy. J Young Pharm.2017; 9(1).

51. Ross JA, Kasum CM, Davies SM, Jacobs DR, Folsom AR, Potter JD. Diet and risk of leukemia in the lowa Women's health study. Cancer Epidemiol Biomark Prev. 2002;11(8):777-81.

52. Lan Q, Zhang L, Li G, Vermeulen R, Weinberg RS, Dosemeci M, Rappaport SM, Shen M, Alter BP, Wu Y. Hematotoxicity in workers exposed to low levels of benzene. Science. 2004:306(5702):1774-6.

53. Qu Q, Shore R, Li G, Jin X, Chi Chen L, Cohen B, Melikian AA, Eastmond D, Rappaport SM, Yin S. Hematological changes among Chinese workers with a broad range of benzene exposures. Am J Ind Med. 2002;42(4):275-85.

54. Khalade A, Jaakkola MS, Pukkala E, Jaakkola JJ. Exposure to benzene at work and the risk of leukemia: a systematic review and meta-analysis. Environ Health. 2010;9(1):31.

55. Steinmaus C, Smith AH, Jones RM, Smith MT. Meta-analysis of benzene exposure and non-Hodgkin lymphoma: biases could mask an important association. Occup Environ Med. 2008;65(6):371-8. 
56. Meek MB, Klaunig JE. Proposed mode of action of benzene-induced leukemia: interpreting available data and identifying critical data gaps for risk assessment. Chem Biol Interact. 2010;184(1-2):279-85.

57. McHale CM, Zhang L, Smith MT. Current understanding of the mechanism of benzene-induced leukemia in humans: implications for risk assessment. Carcinogenesis. 2011;33(2):240-52.

58. Battisti V, Maders LD, Bagatini MD, Santos KF, Spanevello RM, Maldonado PA, Brulé AO. Do Carmo Araújo M, Schetinger MR, Morsch VM. Measurement of oxidative stress and antioxidant status in acute lymphoblastic leukemia patients. Clin Biochem. 2008;41(7-8):511-8.

59. Cronkite E, Bullis J, Inoue T, Drew R. Benzene inhalation produces leukemia in mice. Toxicol Appl Pharmacol. 1984;75(2):358-61.

60. Al-Olayan EM, El-Khadragy MF, Aref AM, Othman MS, Kassab RB, Abdel Moneim AE. The potential protective effect of Physalis peruviana $\mathrm{L}$. against carbon tetrachloride-induced hepatotoxicity in rats is mediated by suppression of oxidative stress and downregulation of MMP-9 expression. Oxid med cell longev.2014; 2014.

61. Winn LM. Homologous recombination initiated by benzene metabolites: a potential role of oxidative stress. Toxicol Sci. 2003;72(1):143-9.

62. El-Shakour AA, El-Ebiarie AS, Ibrahim YH, Moneim AEA, El-Mekawy AM. Effect of benzene on oxidative stress and the functions of liver and kidney in rats. J Environ Occup Sci. 2015:4:34-9.

63. Walz-Mattmüller R, Horny H-P, Ruck P, Kaiserling E. Incidence and pattern of liver involvement in haematological malignancies. Pathol Res and Pract. 1998;194(11):781-9.

64. Luciano RL, Brewster UC. Kidney involvement in leukemia and lymphoma. Adv Chronic kidney dis. 2014; 21(1):27-35.

65. Cerutti P, Ghosh R, Oya Y, Amstad P. The role of the cellular antioxidant defense in oxidant carcinogenesis. Environ Health Perspect. 1994;102(Suppl 10):123.

66. Goto H, Yanagimachi M, Kajiwara R, Kuroki F, Yokota S. Lack of mitochondrial depolarization by oxidative stress is associated with resistance to buthionine sulfoximine in acute lymphoblastic leukemia cells. Leukemia Res. 2007;31(9):1293-301

67. Valko M, Rhodes C, Moncol J, Izakovic M, Mazur M. Free radicals, metals and antioxidants in oxidative stress-induced cancer. Chem Biol Interact. 2006; 160(1):1-40.

68. Al-Gayyar MM, Eissa LA, Rabie AM, El-Gayar AM. Measurements of oxidative stress status and antioxidant activity in chronic leukaemia patients. J Pharm Pharmacol. 2007;59(3):409-17.

69. Veal EA, Toone WM, Jones N, Morgan BA. Distinct roles for glutathione Stransferases in the oxidative stress response in Schizosaccharomyces pombe. J Biol Chem. 2002;277(38):35523-31.

70. Mansour HH, Hafez HF, Fahmy NM. Silymarin modulates cisplatin-induced oxidative stress and hepatotoxicity in rats. J Biochem Mol Biol. 2006;39(6):656.

71. Zhang H, Cao C-M, Gallagher RJ, Timmermann BN. Antiproliferative withanolides from several solanaceous species. Nat Prod Res. 2014;28(22): 1941-51.

72. Oh JH, Lee T-J, Kim SH, Choi YH, Lee SH, Lee JM, Kim Y-H, Park J-W, Kwon TK. Induction of apoptosis by withaferin a in human leukemia U937 cells through down-regulation of Akt phosphorylation. Apoptosis. 2008;13(12): 1494-504.

73. Mandal C, Dutta A, Mallick A, Chandra S, Misra L, Sangwan RS, Mandal C. Withaferin a induces apoptosis by activating p38 mitogen-activated protein kinase signaling cascade in leukemic cells of lymphoid and myeloid origin through mitochondrial death cascade. Apoptosis. 2008;13(12):1450-64.

\section{Publisher's Note}

Springer Nature remains neutral with regard to jurisdictional claims in published maps and institutional affiliations.

Ready to submit your research? Choose BMC and benefit from:

- fast, convenient online submission

- thorough peer review by experienced researchers in your field

- rapid publication on acceptance

- support for research data, including large and complex data types

- gold Open Access which fosters wider collaboration and increased citations

- maximum visibility for your research: over $100 \mathrm{M}$ website views per year

At BMC, research is always in progress.

Learn more biomedcentral.com/submissions 